OPEN ACCESS

Edited by:

Shirley A. Pomponi, Florida Atlantic University,

United States

Reviewed by:

Hermann Ehrlich,

Freiberg University of Mining

and Technology, Germany

Lorenzo Angeletti,

Istituto di Scienze Marine (ISMAR),

Italy

${ }^{*}$ Correspondence:

Eva Martins

eva.martins@i3bs.uminho.pt; eva.biotec@gmail.com

Tiago H. Silva

tiago.silva@i3bs.uminho.pt

${ }^{\dagger}$ Deceased March 7, 2020

Specialty section:

This article was submitted to Deep-Sea Environments and Ecology, a section of the journal

Frontiers in Marine Science

Received: 02 October 2020 Accepted: 04 December 2020

Published: 15 January 2021

Citation:

Martins E, Rapp HT, Xavier JR,

Diogo GS, Reis RL and Silva $T H$ (2021) Macro and Microstructural

Characteristics of North Atlantic Deep-Sea Sponges as Bioinspired Models for Tissue

Engineering Scaffolding.

Front. Mar. Sci. 7:613647. doi: 10.3389/fmars.2020.613647

\section{Macro and Microstructural Characteristics of North Atlantic Deep-Sea Sponges as Bioinspired Models for Tissue Engineering Scaffolding}

Eva Martins ${ }^{1,2 *}$, Hans Tore Rapp ${ }^{3 \dagger}$, Joana R. Xavier ${ }^{3,4}$, Gabriela S. Diogo ${ }^{1,2}$, Rui L. Reis ${ }^{1,2}$ and Tiago H. Silva ${ }^{1,2 *}$

\footnotetext{
'3B's Research Group, Research Institute on Biomaterials, Biodegradables and Biomimetics, Headquarters of the European Institute of Excellence on Tissue Engineering and Regenerative Medicine, AvePark-Parque de Ciência e Tecnologia, University of Minho, Barco, Portugal, ${ }^{2}$ ICVS/3B's-PT Government Associate Laboratory, Guimarães, Portugal, ${ }^{3}$ Department of Biological Sciences, K.G. Jebsen Centre for Deep Sea Research, University of Bergen, Bergen, Norway, ${ }^{4}$ Interdisciplinary Centre of Marine and Environmental Research, University of Porto, Matosinhos, Portugal
}

Sponges occur ubiquitously in the marine realm and in some deep-sea areas they dominate the benthic communities forming complex biogenic habitats - sponge grounds, aggregations, gardens and reefs. However, deep-sea sponges and spongegrounds are still poorly investigated with regards to biotechnological potential in support of a Blue growth strategy. Under the scope of this study, five dominant North Atlantic deep-sea sponges, were characterized to elucidate promising applications in human health, namely for bone tissue engineering approaches. Geodia barretti (Gb), Geodia atlantica (Ga), Stelletta normani (Sn), Phakellia ventilabrum (Pv), and Axinella infundibuliformis (Ai), were morphologically characterized to assess macro and microstructural features, as well as chemical composition of the skeletons, using optical and scanning electron microscopy, energy dispersive $\mathrm{x}$-ray spectroscopy and microcomputed tomography analyses. Moreover, compress tests were conducted to determine the mechanical properties of the skeletons. Results showed that all studied sponges have porous skeletons with porosity higher than 68\%, pore size superior than $149 \mu \mathrm{m}$ and higher interconnectivity (>96\%), thus providing interesting models for the development of scaffolds for tissue engineering. Besides that, EDS analyses revealed that the chemical composition of sponges, pointed that demosponge skeletons are mainly constituted by carbon, silicon, sulfur, and oxygen combined mutually with organic and inorganic elements embedded its internal architecture that can be important features for promoting bone matrix quality and bone mineralization. Finally, the morphological, mechanical, and chemical characteristics here investigated unraveled the potential of deep-sea sponges as a source of biomaterials and biomimetic models envisaging tissue engineering applications for bone regeneration.

Keywords: deep-sea sponges, marine inspired skeletons, biotechnological potential, biomaterials, scaffolds, tissue engineering, biomimetic models, bone regeneration 


\section{INTRODUCTION}

Sponges (phylum Porifera) are the earliest evolving animal lineage (Simion et al., 2017), which have diversified and adapted to a wide range of aquatic, marine and freshwater habitats (Hooper and Van Soest, 2002). Since early studies on blue biotechnology that marine sponges are associated with their great potential for the production of compounds with biomedical, biopharmaceutical, nutraceutical and ecological importance (Kim and Dewapriya, 2012; Wörheide et al., 2012; Shaala et al., 2019). These compounds have contributed in particular to biomedicine and new therapeutics by providing antiviral, antitumor and antimicrobial bioactives (Belarbi et al., 2003; Wang, 2006), but also biomolecules for tissue engineering (TE). The challenge of TE is to stimulate the regeneration process on human tissues restoring the function previously lost due to the malformation or injuries (Christy et al., 2020) and typically relies on the use of templates for 3D cell culture, acting as scaffold for cell anchoring and proliferation, toward the formation of a new tissue. Sponges are characterized by a structure with unique architectures and a wide range of sizes and shapes, thus exhibiting morphological characteristics matching the requirements of the TE templates, suggesting their use in such context. Interestingly, Porifera species have also extraordinary regenerative capacities of the body wall after substantial damage, studied in North Atlantic species such as Geodia barretti (Hoffmann et al., 2003) and Chondrosia reniformis (Nickel and Brümmer, 2003; Pozzolini et al., 2019). However, spatial distribution, competition and food availability are factors that affect the rapid regeneration of marine sponges and their tissues (Bell, 2002).

Sponges comprise more than 8600 species distributed in four taxonomic classes: Hexactinellida, Demospongiae, Homoscleromorpha, and Calcarea (Hooper and Van Soest, 2002; Gazave et al., 2012; Horton et al., 2018), with demosponges displaying the highest number of described species. This class is mainly distinguished by the presence of skeletons characterized by the combination of organic and inorganic materials, such as spongins, collagen-like protein or fibrillar collagens - fibers and siliceous spicules, respectively, embedded into a well-organized fibrous network, which retain nutrients and expel metabolic products (Eckert et al., 2006; Maldonado, 2009; Ehrlich et al., 2018b; Aguilar-Camacho et al., 2019). So far, the spongin has been characterized as a collagen-like protein containing halogenated residues, but its chemical characterization is still a scientific challenge (Ehrlich, 2019). Interestingly, spongins (A and $\mathrm{B}$ ) showed evolutionarily similarities to basement membrane collagens, and type IV collagens (Exposito et al., 2002) and analogous to the human collagen type XIII (Green et al., 2003). Moreover, the skeletal framework of Chondrosia reniformis sponge contains collagenous mesohyl supported by spongin fibers, curiously without any mineral elemental (Hooper and Van Soest, 2002; Silva et al., 2016; Martins et al., 2019). Besides, a small group of demosponges has skeletal framework constituted by calcium carbonate, as aragonite or calcite (Uriz, 2006; Gilis et al., 2013; Smith et al., 2013) or the structural polysaccharide chitin, mainly reported on demosponges from Verongiida and
Poecilosclerida orders (Ehrlich et al., 2007, 2018a; ŻółtowskaAksamitowska et al., 2018).

Chitin is a natural polymer found in other animals as arthropods, crustacean and fungi and its deacetylation resulting in chitosan, that it is a cationic polymer with biocompatible and biodegradability properties (Younes et al., 2014; Philibert et al., 2017; Santos et al., 2020). Chitin and its derivatives are widely use in wound healing, blood anticoagulants, drug delivery, stem cell technology or on fabrication of nanofibers in biomedicine (Singh and Ray, 2000; Azuma et al., 2014; Chiriboga et al., 2020; Singh and Shrivastava, 2020). Furthermore, spongederived chitin scaffolds had been produced maintaining the tubelike chitin skeletal framework in Aplysina archer and Ianthella flabelliformis demosponges envisaging applications in biomedical field such as drug delivery biomaterials (Klinger et al., 2019; Kovalchuk et al., 2019).

Collagen is also a natural polymer present on marine species, such as sponges and fishes, but also, it is a biopolymer ubiquitously present in the human extracellular matrix and connective tissues of animals (Ramshaw et al., 2009; Silva et al., 2014; Alves et al., 2017; Sousa et al., 2020a) that provides spatial and mechanical support to the cells and tissues, thereby receiving strong attention from the biomedical community, with numerous studies addressing its use as a biocompatible material, based on its biodegradability and low immunogenicity for tissue regeneration (Yannas, 1992; Dong and Lv, 2016; Sorushanova et al., 2019; Sousa et al., 2020b). In addition, collagen provides an available biomimetic material for the development of scaffolds for numerous applications, being highly compatible with human systems (Silva et al., 2012; Chattopadhyay and Raines, 2014; Diogo et al., 2020). Collagens are commonly isolated from mammalian (porcine and bovine) but also from marine origins. The application of marine collagens for the development of biomaterials has been shown as a good alternative related to mammal collagens. Marine collagens have been reported as the safest source for obtaining collagen, showing lower antigenicity properties, free of zoonosis (e.g., bovine spongiform encephalopathy), greater absorption due to low molecular weight, minor constraints due to social/religious reasons and regulatory issues. Each type of collagen displays unique structural features varying according to the species and tissues (i.e., anatomical part) from where it is extracted (Silvipriya et al., 2015; Fassini et al., 2020; Seixas et al., 2020).

Silica by itself is a chemical compound that contains silicon, being this a vital element for the growth and formation of bone and cartilage tissues (Jugdaohsingh, 2007). Moreover, biosilica has been reported to increase mineralization by deposition of calcium phosphates as the formation of hydroxyapatite crystallite, inspiring its utilization for the development of new biomaterials envisioning ultimately the regeneration of human bone tissues (Schröder et al., 2005; Müller et al., 2007). Spicules from marine sponges are mainly constituted by biogenic silica namely phytoliths (Clarke, 2003). Besides the chemical composition, architectural features exhibited by sponges are also striking, with skeletal structures hierarchically arranged from the nano- to the macroscale (Aizenberg et al., 2005), influenced by the environmental conditions of each specific hard-bottom 
marine ecosystem and also varying according to the species. Interestingly, sponges have body features similar to anatomic bone structures, in that both are semi-rigid structures with an efficient high interconnected porous architecture composed by inorganic (biosilica or hydroxyapatite) and organic (spongin or collagen) components (Granito et al., 2017). Regarding their morphology, sponges are relatively simple with different cell types specialized in particular biological functions, but not organized into tissues. They are filter-feeding animals with numerous inhalant pores and exhalant oscules, organized waterchannels systems, and interconnected architectures that enable the circulation of water, and retention of microorganisms and organic particles due to the highly efficient filtration properties (De Vos et al., 1991).

This anatomical architecture resembles the requirements needed for the manufacturing of biomaterials for tissue engineering applications. Indeed, the high exchange of fluids is a relevant requisite for the fabrication of artificial bone scaffold to enable the transport and delivery of oxygen and nutrients to the cells cultured in this scaffold and of carbon dioxide and metabolic waste in return (Einhorn and Gerstenfeld, 2015). Additionally, skeletons of sponges have great morphological diversity, plasticity in size and shape necessary for growth (Ehrlich and Worch, 2007; Nakayama et al., 2015), which may represent a variability of mechanical properties that can benefit the culture of cells toward human bone tissue engineering (Green et al., 2003), being more biocompatible than synthetic biomaterials due to the natural related properties. Moreover, marine sponges' skeletons can be used as natural inspired templates in the biomedical field related to their chemical composition and wide range of unique properties. Also, the development of biomaterials using biomolecules as collagens, peptides or biogenic silica with marine nature origin can be used for stimulating the biomineralization and consequently enhancement the regeneration process (Fassini et al., 2017; Gabbai-Armelin et al., 2019). Moreover, the remarkable regenerative capacity of sponges has been documented in several demosponges as Geodia barretti (Hoffmann et al., 2003), Halisarca dujardini (Borisenko et al., 2015), Hymeniacidon heliophila (Coutinho et al., 2017) and Aplysina cavernicola (Ereskovsky et al., 2019). Interestingly, it has been reported the regenerative signaling proteins (TGF- $\beta$ and Wnt) in bone therapeutics are also discovered during the early developmental stages of marine sponges (Suga et al., 1999; Green et al., 2013; Pozzolini et al., 2019). The natural organisms have natural frameworks and powerfully regenerative capacity and accessible extraordinary sources of biomolecules, some of which conserved throughout evolution. Given the evidence of the existence of analogous properties between bone and marine sponges, highlighting the use of sponge derived proteins as potentially be used to regenerate living bone or the marine sponges' architectures or in combination with growth factors (IGF-1 and BMP-2), are promising frameworks for bone repair and augmentation (Nandi et al., 2015).

The original form of the sponge architectures has been investigated as potential scaffolds for tissue engineering and regenerative medicine, as in an effort to mimic native extracellular matrix, feasibility biomatrices and prompting the self-sustaining tissues support. This capability of scaffolding properties is mainly inspired firstly in the hierarchical design; one of the natural pre-designed structure adjusting it for a novel purpose addressing specific clinical challenges related to the aspects that promote the natural cycle of regeneration process. Furthermore, biomimetic strategies have led to the study of naturally the marine sponges skeletons envisaging their hierarchical design or complex forms for use as bioscaffolds fabrication with key suitable properties for favorable human implantation (Martins et al., 2019). For instance, Ianthella labyrinthus demosponges revealed a naturally $3 \mathrm{D}$ pre-structured porous chitin-based skeleton with high biomimetic and biomimesis potential that promote the culture of cardiomyocytes cells demonstrating interesting features for biomedical application for having absorbable hemostats properties (Schubert et al., 2019). Additionally, Ianthella basta and Aplysina aerophoba demosponges have been used as a promising stem cell-based scaffold, showing high biocompatibility with human mesenchymal stromal cells (Mutsenko et al., 2017b) but also were capable to differentiate into chondrogenic, adipogenic and osteogenic lineages (Mutsenko et al., 2017a). Recently, sophisticated microspheres had developed using the sterrasters spicules of Geodia macandrewii showing non-cytotoxicity and osteogenic ability envisaging bone tissue engineering and drug delivery applications (Kaya et al., 2020). Other examples include the use of bioglass-based scaffolds prepared using Spongia agaricina and Spongia lamella as templates for attaining higher mechanical properties in the scaffolds (Boccardi et al., 2015a) or S. agaricina in the development of ceramic bone scaffolds (Cunningham et al., 2010; Clarke et al., 2016).

Geodia barretti (Bowerbank 1858), Geodia atlantica (Stephens, 1915), Stelletta normani (Sollas, 1880) Phakellia ventilabrum (Linnaeus, 1767), and Axinella infundibuliformis (Linnaeus, 1759) are five species representative of the deep-sea grounds as part of different taxonomic groups (Figure 1), occurring in high density and biomass in the boreal North Atlantic (Klitgaard and Tendal, 2004; Murillo et al., 2012). In this study, the skeletons of these species were characterized, mainly focusing on macro and microstructures and consecutively highlighting the potential of these marine sponges as nature-inspired templates for tissue engineering.

\section{EXPERIMENTAL SECTION}

\section{Sponges Collection and Processing}

Specimens of Geodia barretti (Gb), Geodia atlantica (Ga), Stelletta normani ( $\mathrm{Sn})$, Phakellia ventilabrum (Pv), and Axinella infundibuliformis (Ai) (Figure 2) were collected on September, 2016 at Korsfjord, Norway using a triangular dredge (Table 1). Upon collection, specimens of each species were sub-sampled and preserved in absolute ethanol until further analyses.

\section{Macrostructural Analyses}

Sponges immersed with absolute ethanol were cut in $1 \mathrm{~cm}^{3}$ small pieces and dried using a critical point dryer (Tousimis 


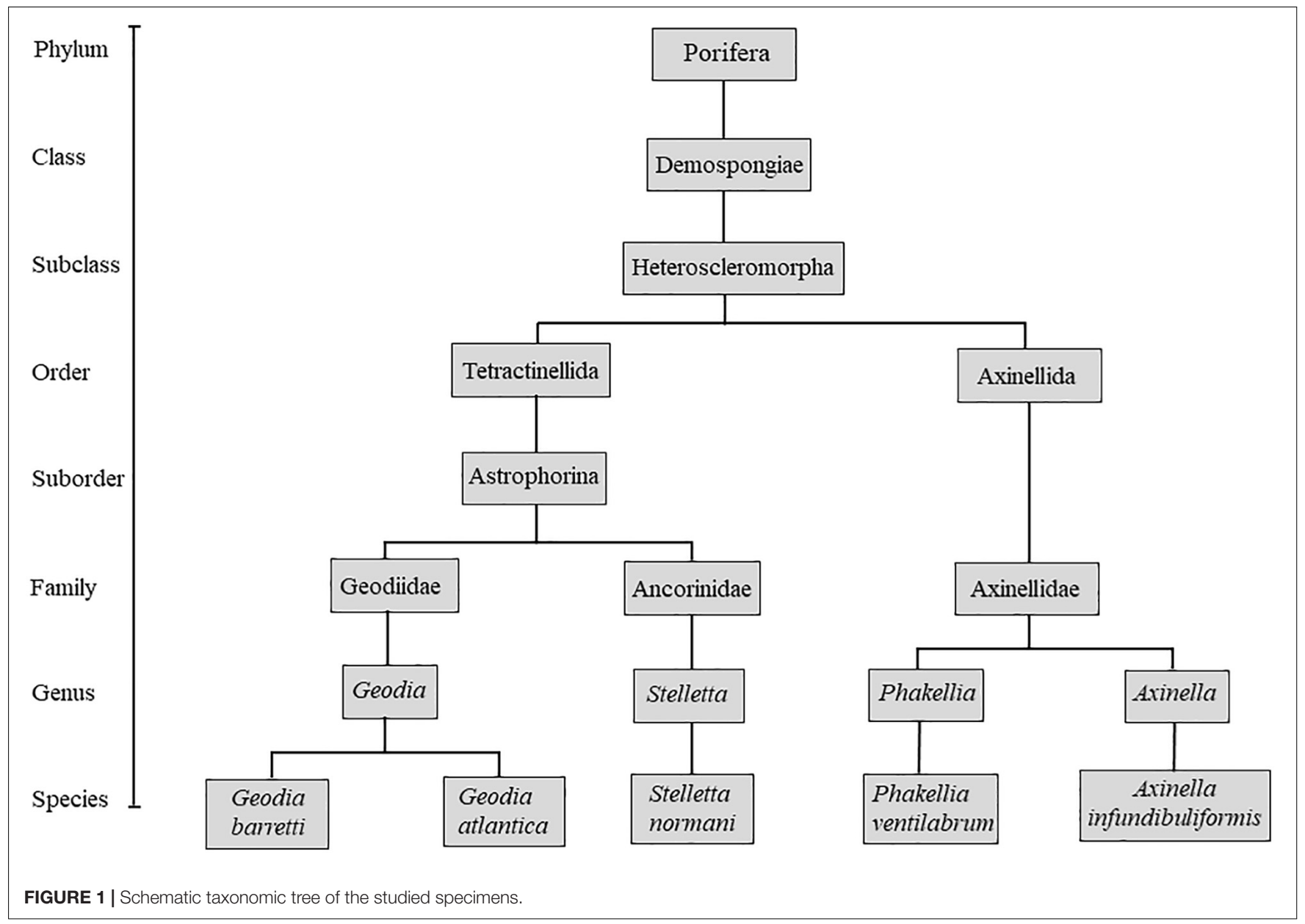

Autosamdri $815^{\circledR}$ series). After this procedure, the acquisition of sponge images was taken using a stereomicroscope (Stemi 1000. ZEISS) equipped with a camera selecting the same photographic parameters (zoom and magnification) for all the specimens (Figure 3).

\section{Scanning Electron Microscopy}

Scanning electron microscopy (SEM) was used to analyze the surface morphology of the sponges using an analytical scanning electron microscope (JSM-6010 LV, JEOL, Japan), using a beam energy of $10 \mathrm{keV}$ at various levels of magnification. After five sponge species were critical point dried, specimens were sputter-coated with an electrically conducting layer of platinum using the EM Leica ACE600 Sputter coater, before starting the SEM analysis.

\section{Energy Dispersive X-Ray Spectroscopy}

Energy dispersive X-ray spectroscopy (EDS) was used to characterize the chemical composition of the sponge architectures, regarding the relative quantity of the chemical elements present their skeletons. EDS analysis was performed in general landscape of the outermost sponge surface and in the spicule elements structures using the INCAx-Act,
PentaFET Precision Oxford Instruments at an energy of $10.0 \mathrm{keV}$ coupled to SEM.

\section{Microcomputed Tomography}

Microcomputed tomography $(\mu \mathrm{CT})$ was used for visualization and analyses of the microstructure of marine sponges. The data acquisition was performed on a high-resolution $\mu \mathrm{CT}$ equipment Skycan 1272 (Bruker, Kontich, Belgium) using a series of about 374 projections and a dynamic threshold of 30-255, with a rotation range of $360^{\circ}$, and a resolution of $12 \mu \mathrm{m}$ after X-ray beam penetrates the samples. The organic and inorganic ratios of sponges were determined considering a threshold of 30-60 for the organic matter represented in red color gradient and 60-255 for the inorganic matter in green color gradient. The $\mathrm{X}$-ray source was set at $50 \mathrm{kV}$ of energy and a current of $200 \mu \mathrm{A}$.

Noise was reduced and representative data were reconstructed using nRecon ${ }^{\circledR}$ software, while CT Analyzer ${ }^{\circledR}$ software was used to re-slice all the files of each sample and determine various morphometric parameters such as porosity $(\%)$, pore size $(\mu \mathrm{m})$, the degree of anisotropy (DA) and pore interconnectivity (\%). Each of the parameters was determined in triplicates, with data presented as the mean \pm standard deviation. CTVox ${ }^{\circledR}$ program was used for the $3 \mathrm{D}$ reconstruction of the sponges and video processing. 


\section{Marine sponges}

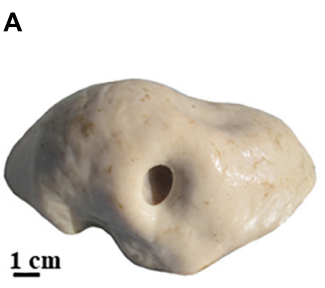

Geodia barretti
B

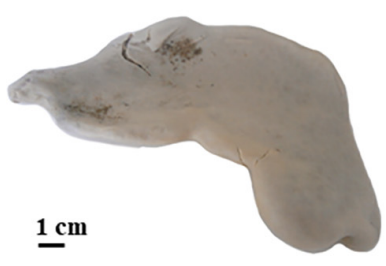

Geodia atlantica

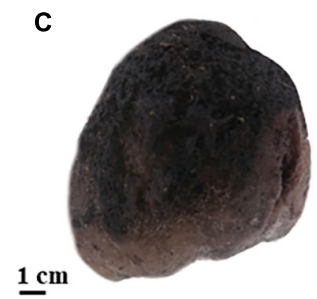

Stelletta normani
D

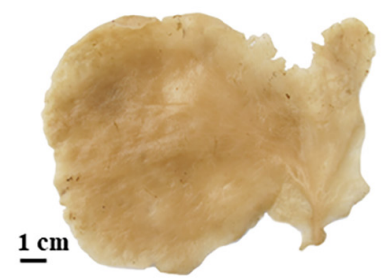

E

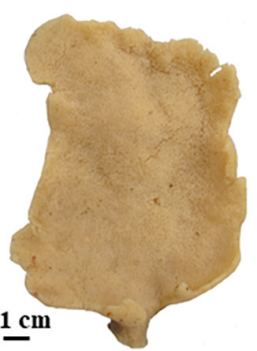

Phakellia ventilabrum Axinella infundibuliformis

FIGURE 2 | Five marine sponges studied of North Atlantic, namely G. barretti (A), G. atlantica (B) and S. normani (C), P. ventilabrum (D), and A. infundibuliformis (E),

TABLE 1 | Stations and sponge species in which Geodia barretti (Gb), Geodia atlantica (Ga), Stelletta normani (Sn), Phakellia ventilabrum (Pv), and Axinella infundibuliformis (Ai) were recovered.

\begin{tabular}{|c|c|c|c|c|c|c|c|}
\hline Species & Station & Start lat. & Start long. & Start depth (m) & End lat. & End long. & End depth (m) \\
\hline$G b$ & 2 & $59^{\circ} 58.8790^{\prime} \mathrm{N}$ & $5^{\circ} 22.4371^{\prime} \mathrm{E}$ & 332 & $59^{\circ} 58.8879^{\prime} \mathrm{N}$ & $5^{\circ} 22.7268^{\prime} \mathrm{E}$ & 97.3 \\
\hline $\mathrm{Ga}$ & 2 & $59^{\circ} 58.8790^{\prime} \mathrm{N}$ & $5^{\circ} 22.4371^{\prime} \mathrm{E}$ & 332 & $59^{\circ} 58.8879^{\prime} \mathrm{N}$ & $5^{\circ} 22.7268^{\prime} \mathrm{E}$ & 97.3 \\
\hline Sn & 2 & $59^{\circ} 58.8790^{\prime} \mathrm{N}$ & $5^{\circ} 22.4371^{\prime} \mathrm{E}$ & 332 & $59^{\circ} 58.8879^{\prime} \mathrm{N}$ & $5^{\circ} 22.7268^{\prime} \mathrm{E}$ & 97.3 \\
\hline$P V$ & 2 & $59^{\circ} 58.8790^{\prime} \mathrm{N}$ & $5^{\circ} 22.4371^{\prime} \mathrm{E}$ & 332 & $59^{\circ} 58.8879^{\prime} \mathrm{N}$ & $5^{\circ} 22.7268^{\prime} \mathrm{E}$ & 97.3 \\
\hline$A i$ & 5 & $59^{\circ} 48.8155^{\prime} \mathrm{N}$ & $5^{\circ} 36.2325^{\prime} \mathrm{E}$ & 292 & $59^{\circ} 48.9226^{\prime} \mathrm{N}$ & $5^{\circ} 35.8771^{\prime} \mathrm{E}$ & 226 \\
\hline
\end{tabular}

\section{Mechanical Properties}

Mechanical properties of the five species were determined using the Instron 5540 universal mechanical testing equipment with a $50 \mathrm{~N}$ load cell in compressive mode. Eight replicates of each sponges were tested and compressed perpendicularly to the printing plane at a crosshead speed of $1 \mathrm{~mm} / \mathrm{min}$ up to $30 \%$ strain. Compressive modulus was determined from the stressstrain curve specifically the slope of the linear region using Bluehill Universal software.

\section{Statistical Analyses}

Statistical analyses were performed using GraphPad Prism 8.0.1 software. Data are presented as the mean \pm standard deviation of a least three samples. Non-parametric Kruskal-Wallis tests, following Dunn's multiple comparisons were used for determination of significance level with $p$-value less than 0.05 $(p<0.05)$ being considered statistically significant.

\section{RESULTS AND DISCUSSION}

\section{Macrostructural Characterization}

To comprehend the peculiarities in skeletons of these five studied sponge species, the morphology characterization was addressed. For that, Gb, Ga, Sn, Pv, and Ai specimens were photographed and stereomicroscope images are represented in Figures 2, 3, illustrating their macrostructure with visualization of the relevant morphological features. These sponges are constituted by a dense and elastic tissue with highly absorbable capacity due to the presence of pores in their skeletons. The studied species showed differences in terms of their overall morphology and 


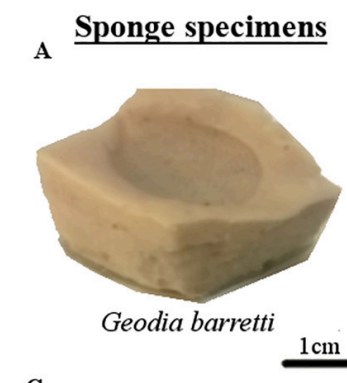

C

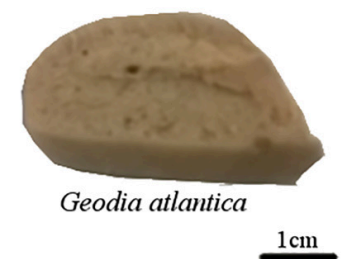

$\mathbf{E}$

G
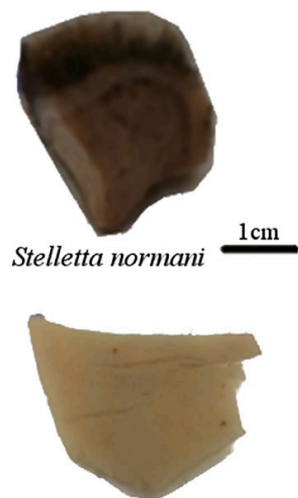

Phakellia ventilabrum

I

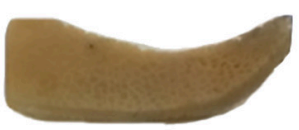

Axinella infundibuliformis

$1 \mathrm{~cm}$
Dried sponge images
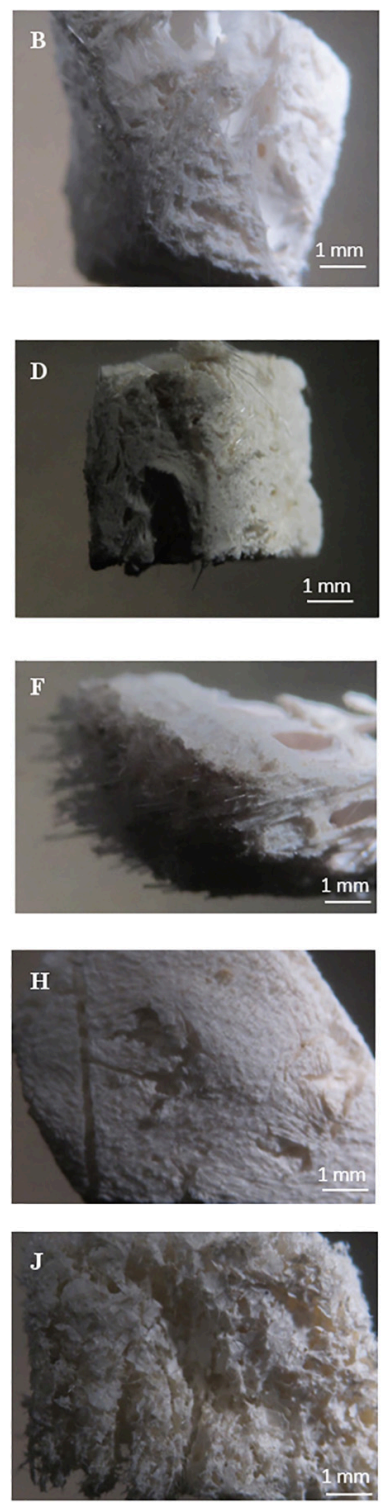

FIGURE 3 | North Atlantic marine sponge macrostructures. Sponge photographs of each specimen took after removal the absolute ethanol (A,C,E,G,I) and stereomicroscope images of sponge specimens after critical point drying $(\mathbf{B}, \mathbf{D}, \mathbf{F}, \mathbf{H}, \mathbf{J})$.

macrostructure properties. While the tetractinellids $\mathrm{Ga}, \mathrm{Gb}$ (family Geodiidae), and Sn (family Ancorinidae) exhibit a massive (sub)spherical morphology with a clear distinction of a cortical layer, the axinellids $\mathrm{Pv}$ and $\mathrm{Ai}$ are typically lamellate or cup-like with a small stalk and lack such a specialized ectosomal layer. Particularly Geodia species ( $\mathrm{Ga}$ and $\mathrm{Gb}$ ), the cortex essentially composed by a layer of sterraster, a spicule element typical for the family of the Geodiidae. Regarding $\mathrm{Pv}$ and $\mathrm{Ai}$ specimens exhibit thin walls of fibrous matrix tissues (Figure 2); however, $\mathrm{Pv}$ showed a more compact and less porous macrostructure (Figures $\mathbf{3 G}, \mathbf{H}$ ) than their relative $\mathrm{Ai}$ (Figures 3I,J).

\section{Microstructural Characterization}

The microstructural assessment of sponge (Gb, Ga, Sn, Pv, and $\mathrm{Ai}$ ) was performed by SEM, aiming to analyze the morphological features of the specimens such as their surface architecture, distribution of morphological elements, as the siliceous spicules and pores structures and EDS analysis was also used to determine the chemical elements present on the sponge skeletons and spicules. Additionally, micro-CT images were obtained to examine the internal architecture of the specimens using a non-destructive and non-invasive method, particularly to evaluate porosity, pore size and interconnectivity, as well as anisotropy properties. The sponge skeletons have the exclusive microscopic features and composition, that the detail of these characterizations can highlight details for use in biomimetic approaches or as inspired models for reproducing both or only organic and inorganic elements, for several biomedical applications.

\section{SEM Analysis}

Scanning electron microscopy micrographs of the different $\mathrm{Gb}, \mathrm{Ga}, \mathrm{Sn}$ (Figure 4), $\mathrm{Pv}$, and $\mathrm{Ai}$ (Figure 5) specimens showed outstanding architectures with a variety of organic and inorganic skeletal elements. These SEM images can provide not only the superficial architectural features of sponges but also the pore characteristics, reveal host-microbial associations, reproduction and regeneration mechanisms that remain not completely understood in the marine sponges.

Geodia is distinctively characterized by the presence of unique ball-shaped spicules, the sterrasters that constitute part of the perceptible cortex (Uriz, 2002; Hoffmann et al., 2003; Cárdenas et al., 2013). The type and shape of spicules enable the identification of the Geodia species. Gb showed different clad and sterraster shapes in the spicule elements (Figures 4AC). Indeed, Ga has similar general structural features fitted with the skeletal elements and fibrous layer (Figures $4 \mathrm{E}, \mathbf{F}$ ) like as the $\mathrm{Gb}$ relative, namely the presence of analogous shapes of the spicules. Both Geodia showed conservative morphological features, showing the cortex with a layer microscleres supported by radially arranged megascleres (dichotriaenes). Generally, the megascleres are elongated spicules that concoct the main architecture of skeleton and the microscleres have ancillary functions, adopting different sizes and shapes. Sharply, SEM micrographs demonstrated similarities on the morphological characteristics with visible ectossomal specialization between these two species (Figures $4 \mathbf{A}, \mathbf{E}$ ), and the presence of the microscleres spicules (sterrasters) (Figures 4C,G).

The Sn sponges have mainly siliceous spicules elements with similar needle-like shapes, the megascleres (pro/dichotriaenes and oxeas), hierarchically well-oriented in the ectossomal layer (Figures 4I-L). It is possible to observe an outer rigid layer of spicules (Figure 4G) which confers support and protection of cells in the marine environment (Burns and Ilan, 2003). In addition, the spicules function as an anchoring structure with robust mechanical properties enabling the fixation of the sponge to the substrate.

Phakellia ventilabrum has thinner walls and a sharp-edged rim to its cup. Internally, $\mathrm{Pv}$ sponge showed an architecture formed by a denser mesohyl pierced by megascleres (styles) 


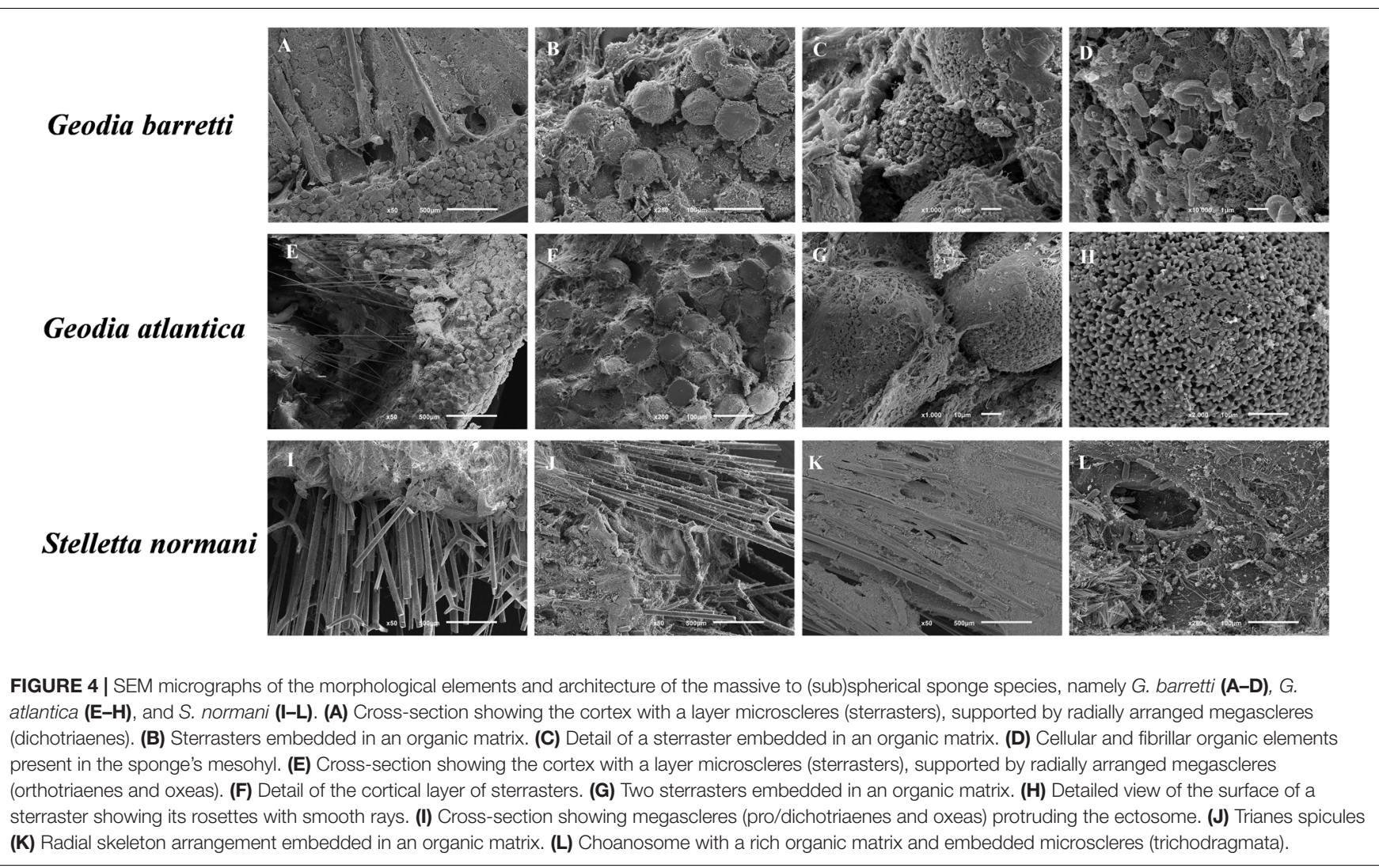

and aquiferous system with different pores and inner organic matrix (Figures 5A-F). Indeed, the sponge structure may harbor diverse microbiota such as protozoa, bacteria, fungi, microalgae, archaea, being therefore described as a holobiont (Webster and Taylor, 2012), with the ones showing high abundance of microbial communities being associated to a more efficient nutritional capability for feed the dissolved organic matters (Yahel et al., 2003).

The skeletal framework of the Ai has a set of diverse shapes of spicules attached (styles and oxeas) in the collagenous mesohyl layer (Figures 5G-I). Interestingly, cellular elements (as sperm cells) had been visualized (Figures 5J-L). The high density of globular cells evidences a reproduction mechanism in Ai sponges and the capability of this species produced gemmules probably linked with the high regeneration capability of the marine sponges. The members of Axinellidae, $\mathrm{Pv}$ and $\mathrm{Ai}$ showed visible differences in their porous architecture, with $\mathrm{Pv}$ showing a denser framework structure when compared to the $\mathrm{Ai}$ sponges (Figure 5).

Succinctly the skeletons of these sponges have unique spicules in a 3D collagenous matrix that facilitates tissue development and transfer water and nutrient mass.

\section{EDS Analysis}

Energy dispersive X-ray spectroscopy was performed to determine the different chemical elements present on the surface and particularly on the spicules of the analyzed sponges, as well as their relative ratios, with the obtained results being depicted in Table 2. The surface of Gb and Ga revealed higher composition in carbon (53.8 and 61.0\%) and oxygen (34.7 and $34.2 \%$ ), respectively. Additionally, other chemical elements, such as sulfur, silicon, phosphorus, magnesium, and sodium, were also found on the surface of Geodia specimens, although in smaller proportion, suggesting that the surface of the deep-sea sponges, although being mostly organic, have a composite nature. According to literature, sulfur element, had been reported in the skeletons of verongiid demosponges (Ehrlich et al., 2010; Klinger et al., 2019) and sodium, chlorine, sulfur, calcium, potassium are the major trace elements found in the spicules and siliceous sponge skeletons. These elements are also present in seawater (Sandford, 2003).

Spicules elements of $\mathrm{Gb}$ specimen had high content of carbon $(23.0 \%)$, oxygen $(51.4 \%)$, and silicon $(24.8 \%)$, whereas in the spicule of $\mathrm{Ga}$ species, oxygen (57.1\%) and silicon (39.6\%) were the most representative elements. Interesting, results pointed to the differences on the spicule composition between the two Geodia species. Results demonstrated that the spicules of $G$. atlantica have a high inorganic nature with a reduce carbon ratio compared to G. barretti. The surface of $\mathrm{Sn}, \mathrm{Pv}$, and Ai sponges had high contents in carbon (50.2, 57.0, and 56.6\%, respectively) and oxygen (38.6, 28.5, and $36.3 \%$, respectively). Similarly, the spicules of these species showed high content of carbon, silicon and oxygen, which seems to be related to the composition in the silicon presenting in nature as silicic acid $\left[\mathrm{Si}(\mathrm{OH})_{4}\right]$ (Wysokowski et al., 2018). 


\section{Phakellia ventilabrum}

\section{Axinella infundibuliformis}
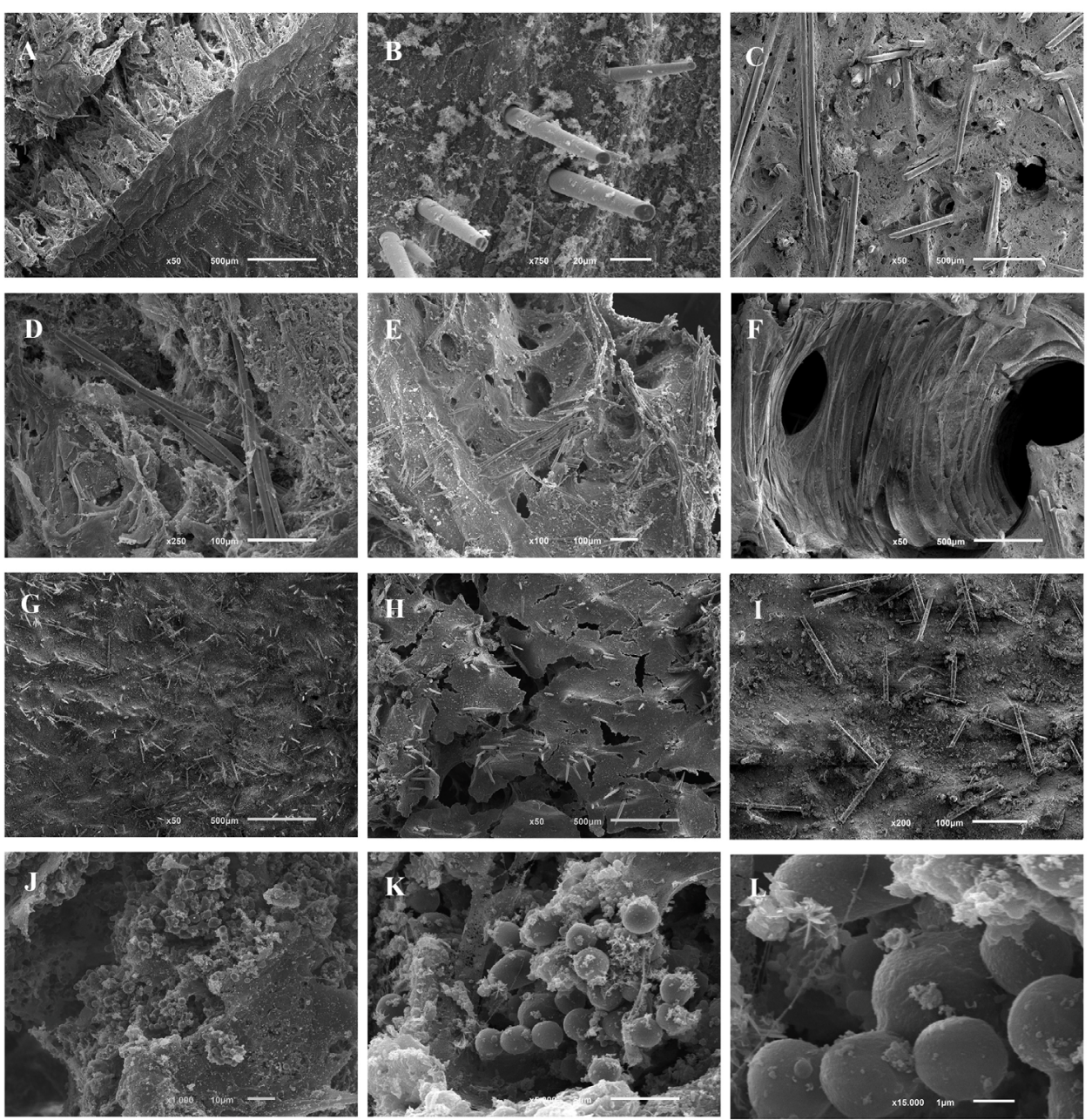

FIGURE 5 | SEM micrographs of the morphological elements and architecture of the flabellate sponge species, namely P. ventilabrum (A-F) and A. infundibuliformis (G-L). (A) Cross-section showing megascleres (styles) piercing the sponge surface. (B) Detail of the surface with protruding spicules. (C-E) Various views of the organic matrix with embedded megascleres (styles and strongyles). (F) Aquiferous system with channel interconnected by different pores and inner organic matrix. $\mathbf{( G , H ) ~ S p o n g e ~ s u r f a c e ~ w i t h ~ o r g a n i c ~ m a t r i x ~ a n d ~ s k e l e t a l ~ e l e m e n t s ~ ( s t y l e s ~ a n d ~ o x e a s ) . ~ ( J - K ) ~ C e l l u l a r ~ e l e m e n t s ~ ( l i k e l y ~ s p e r m ~ c e l l s ) ~ e m b e d d e d ~ i n ~ t h e ~ i n n e r ~ o r g a n i c ~ m a t r i x . ~}$

TABLE 2 | Elemental composition weight (\%) from the general morphological surface of marine sponge specimens (Gb, Ga, Sn, Pv, and Ai) and from their spicule structures obtained by EDS analysis.

\begin{tabular}{|c|c|c|c|c|c|c|c|c|c|c|c|c|}
\hline & & $C$ & 0 & $S$ & Si & $P$ & $M g$ & $\mathrm{Na}$ & $\mathrm{Ca}$ & $\mathrm{Cl}$ & $K$ & $A I$ \\
\hline$G b$ & Wt (\%) & 53.8 & 34.7 & 3.4 & 0.6 & 0.6 & 1.1 & 2.6 & 1.6 & 1.6 & - & - \\
\hline Gb spicule & Wt (\%) & 23 & 51.4 & - & 24.6 & - & - & 0.9 & - & - & - & - \\
\hline Ga & Wt (\%) & 61.0 & 34.2 & 1.3 & 0.9 & 0.9 & 0.7 & 1.0 & - & - & - & - \\
\hline Ga spicule & Wt (\%) & 3.4 & 57.1 & - & 39.6 & - & - & - & - & - & - & - \\
\hline$S n$ & Wt (\%) & 50.2 & 38.6 & 3.6 & 3.4 & - & 0.6 & 2.1 & - & - & - & 1.4 \\
\hline Sn spicule & Wt (\%) & 3.9 & 57.8 & - & 37.2 & - & - & - & - & - & - & 1.1 \\
\hline$P V$ & Wt (\%) & 57.0 & 28.5 & 5.5 & 1.0 & - & 0.5 & 1.8 & 4.6 & - & 1.0 & - \\
\hline Pv spicule & Wt (\%) & 50.7 & 32.0 & 1.8 & 11.4 & - & - & 0.9 & 2.2 & - & 1.0 & - \\
\hline$A i$ & Wt (\%) & 56.6 & 36.3 & 2.5 & 1.9 & 1.6 & 1.1 & - & - & - & - & - \\
\hline Ai spicule & Wt (\%) & 28.9 & 47.9 & - & 23.2 & - & - & - & - & - & - & - \\
\hline
\end{tabular}

The main differences of chemical composition among the five studied sponges are the presence of chlorine element in the surface of $G$. barretti, aluminum element in the surface and spicule structure of $S$. normani and the presence of potassium element in the both the analyzed structures of $P$. ventilabrum. On the other hand, the magnesium element is only found 
on the surface of the five species and being absent on their spicule structures.

The two Geodia species and A. infundibuliformis own their surface have the phosphorus, distinctly not found in S. normani and $P$. ventilabrum sponges, calcium and chlorine elements are disparately present on the surface structure of G. barretti and not in other Geodia relative.

The element of sodium is not present either in surface and spicules structures of A. infundibuliformis. However, sodium element is found on the surface of the two G. barretti, P. ventilabrum, and S. normani species and also in the spicules of G. barretti and P. ventilabrum.

The EDS results (Table 2) suggested that the design of sponge architecture might be influence by chemical composition among the five studied species. Sponges with skeletal architecture more compact $(\mathrm{Gb}$ and $\mathrm{Pv}$ ) suggested incorporating in their skeletal structure a higher diversity of chemical elements than the Ai sponges.

\section{Microcomputed Tomography}

The internal density structure of the five key species was accessed using the Micro-CT analysis, a non-destructive way that preserves the natural sponge skeletons (Figure 6). Firstly, sponges were acquired using an X-ray diffraction displaying the following $\mu \mathrm{CT}$ images in Figures 6A,E,I,M,Q. The other series of $\mu \mathrm{CT}$ images is the $3 \mathrm{D}$ reconstruction of the sponge skeletons and the internal structure. The red or green color $\mu \mathrm{CT}$ images represent the organic and inorganic matter of the marine sponge skeletons, respectively. These images of a longitudinal-sectioned sponge body showed that internal structure formed by a spatial arrangement of the skeleton and inorganic structure, the spicules (Figure 7). A video of sponges reconstruction by micro-CT was included as Supplementary Material. Also, a quantitative analysis of the microstructural and morphometric parameters of the sponges were analyzed. The porosity (P, \%), pore size, interconnectivity (I, \%) and degree of anisotropy of each of the sponge species were evaluated by analysis of the respective 3D reconstructed image, defining an appropriate region of interest. $\mathrm{Gb}, \mathrm{Ga}$, and Sn have massive (sub)spherical shapes whereas $\mathrm{Pv}$ and Ai showed a morphological structure with a flabellate shape. These differences can be confirmed by tomography micrographs (Figures 6, 7). For specimen Gb, P, and I were $84 \pm 3$ and 99, respectively, whereas for $\mathrm{Ga}, \mathrm{P}$, and I were $92 \pm 3$ and 100 , respectively. For Sn specimen, P and I were $82 \pm 1$ and 99 , respectively. For Ai specimen, $\mathrm{P}$ and I were $88 \pm 1$ and 99.8, respectively. The more compact sponge analyzed was $\mathrm{Pv}$, which showed a percentage of $\mathrm{P}$ and $\mathrm{I} 68 \pm 7$ and $96 \pm 2$.

\section{Porosity level and interconnectivity}

All the sponge samples evaluated by $\mu \mathrm{CT}$ had porosity above $68 \%$, and mostly above $80 \%$ that only includes interconnected pores. Moreover, porosity and interconnectivity of $\mathrm{Pv}$ and $\mathrm{Ga}$ sponges were statistically different with $p=0.0153$ and $p=0.0151$, respectively. Moreover, interconnectivity parameter revealed statistical significance between $\mathrm{Pv}$ and Ai sponges $(p=0.0393)$. Indeed, sponge samples had a high interconnectivity of pores, with values of about $99 \%$ in the Gb, Ga, Sn, and Ai sponges and slightly lower, 96\%, for Pv (Figures 8A,B). In fact, high values of porosity and pore interconnectivity reflect crucial properties of filter-feeding animals, which feed occurs by sieving suspended food particles from water, typically by passing the water over specialized filtering structures and choanocyte cells, thus taking advantage of a hierarchical and complex system of pores and channels. This is quite interesting from a biomimetic perspective, as in tissue engineering, the panoply of developed scaffold biomaterials are characterized by a variety of requirements, among which the existence of a system capable to support cell migration and the exchange of oxygen, nutrients and waste is of paramount importance (Gao et al., 2017). In this regard, scaffolds with a porosity between 40 and $90 \%$ envisaging the engineering of bone tissue have been shown to enable cell adhesion and promote a proper osteointegration (Karageorgiou and Kaplan, 2005).

\section{Pore size and degree of anisotropy}

The 3D internal structure of the analyzed sponges showed pore sizes higher than $100 \mu \mathrm{m}$ more particularly ranging from 149 to $472 \mu \mathrm{m}$ (Figure 8C). Pv sponges showed a denser skeleton characterized by the lowest porosity of the studied species, revealing as well smaller pores, with an average size around $149 \mu \mathrm{m}$, comparing to the other sponge species where the average pore size is $300 \mu \mathrm{m}$ and above. Moreover, the pore size of $\mathrm{Ga}$ and $\mathrm{Pv}$ showed statistical differences $(p=0.0162)$. The results of the pore sizes of $\mathrm{Pv}$ sponges suggested that small pores (Figures 5C,E,F) may allow the anchorage of microorganisms, and but also evidencing a strong correlation of a denser mesohyl structure with slower filtration rates, as previously reported (Weisz et al., 2008).

The anisotropy is a property exhibited by the substances and materials showing variations in physical properties dependent on the direction. Conversely, an isotropic structure exhibits the same physical properties independently of direction view (Mitchell and Tojeira, 2013).

Among the studied sponges, the degree of anisotropy of Gb, $\mathrm{Ga}$, and Sn sponges showed values above 0.5 , trending to a strategic alignment of fibers and skeletal structures (Figure 8D). This alignment of fibers on their skeletons can be an important role in the transport of nutrients along with architecture on the sponges when sponges have a more complex organization. The Pv and Ai members of the Axinellidae family showed an isotropic structure endowed with skeletons organized with the same physical characteristics in all directions. According to the statistical analyses, this property was significant between the $\mathrm{Sn}$ and Ai sponges ( $p=0.0148)$, where $S n$ sponge had a degree of anisotropy above 0.5 (the highest value $0.72 \mathrm{DA}$ ) comparing with Ai sponges that have isotropy skeleton with a lower value $(0.27$ DA) below of 0.5 (Figure 8D).

\section{Determination of organic and inorganic ratio}

For the studied sponges, the organic/inorganic ratio was determined by micro-CT from the characteristic differences in the density between these two classes of materials (Figure 9).

All the analyzed demosponges (Gb, Ga, Sn, Pv, and Ai) showed similar ratio of inorganic and organic matter, with a value of around $50 \%$ of each component in the matrix (Figure 9) obtained 


\section{$\underline{\text { X-ray diffraction }}$}

A

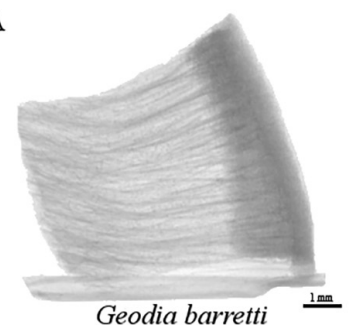

E

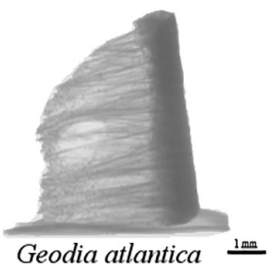

I

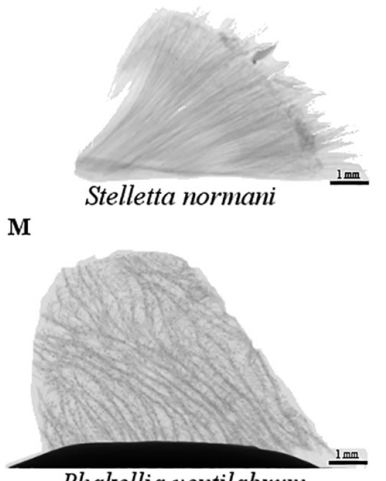

Q

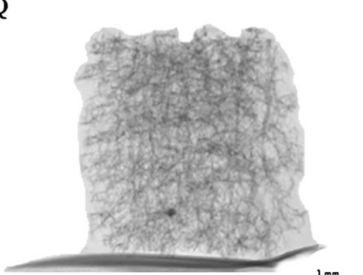

Axinella infundibuliformis
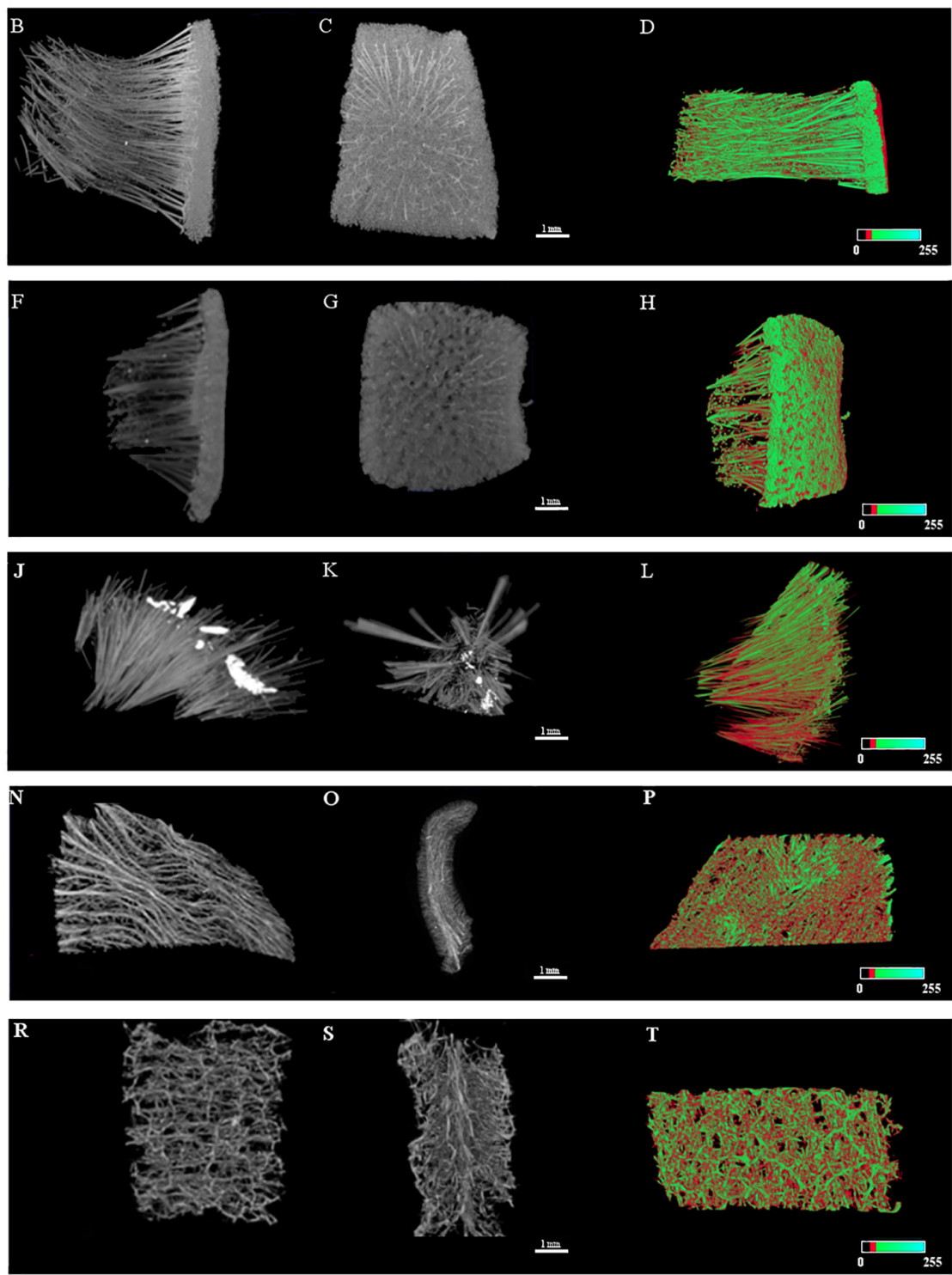

FIGURE 6 | Micro-CT micrographs of the internal microstructure of Geodia barretti (Gb), Geodia atlantica (Ga), Stelletta normani (Sn), Phakellia ventilabrum (Pv), and Axinella infundibuliformis (Ai). The X-ray diffraction images of the internal microstructure acquired for the five specimens (A,E,I,M,Q) respectively, following the order mentioned above. The other series of images represent the three-dimensional (3D) reconstruction. The gray levels micrographs represent two $X$-ray attenuation in different virtual position (B, C,F,G,J,K,N,O,R,S). The color micrographs represent the distribution of organic (red) and inorganic (green) matter (D,H,L,P,T).

by micro-CT analysis. The skeletons of these marine sponges are fibrous framework composed by organic component rich in a collagenous extracellular matrix that promotes attachment of cells (Green et al., 2003), namely spongin and collagenlike proteins, but also inorganic component as spicules. These elements are combined in a specific spatial arrangement on the healthy sponge skeleton, functioning as the mechanical support of the sponges (Taylor et al., 2007). The results suggested that the inside of the spicules are formed by organic material and outer layer is formed by the inorganic material (Figure 7). Statistical analyses showed non-significant differences $(p>0.05)$ in all multiple comparisons between the organic/inorganic content among the five studied sponges.

\section{Mechanical Properties}

To understand the particularities of the sponge skeletons is important to determine the mechanical properties present on the sponge porous internal structure. The compressive modulus for 

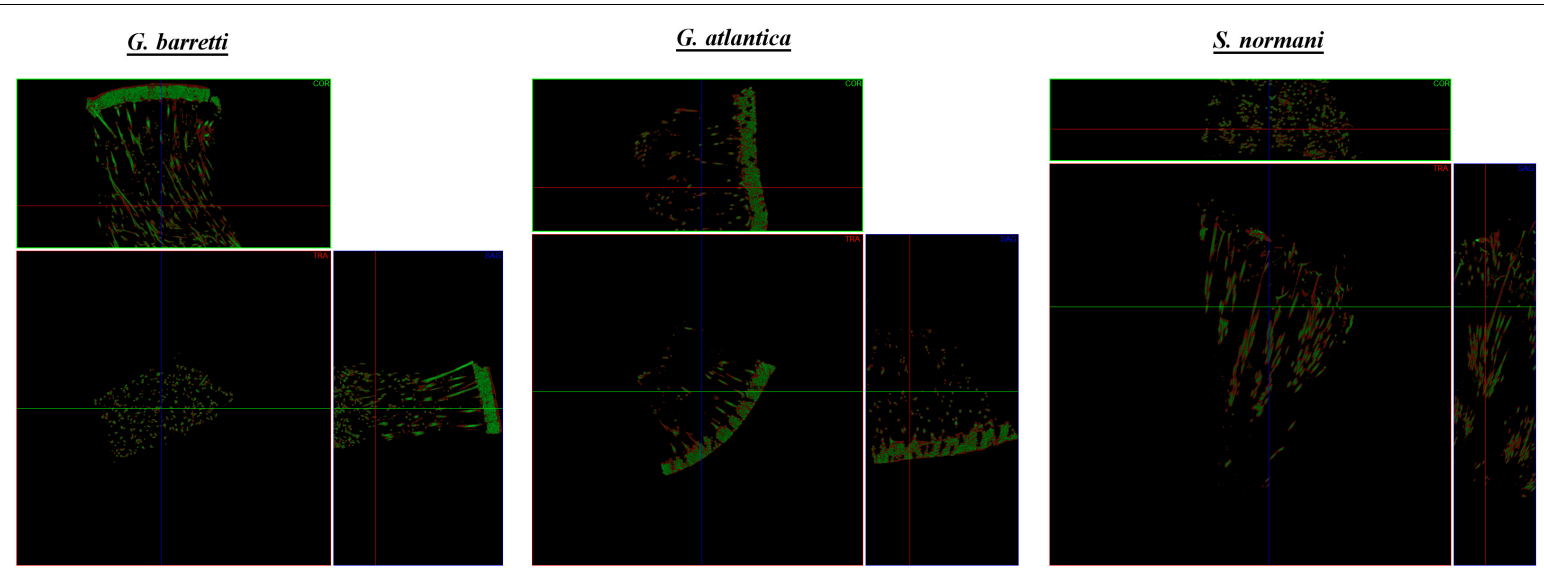

$\underline{\text { P. ventilabrum }}$

A. infundibuliformis
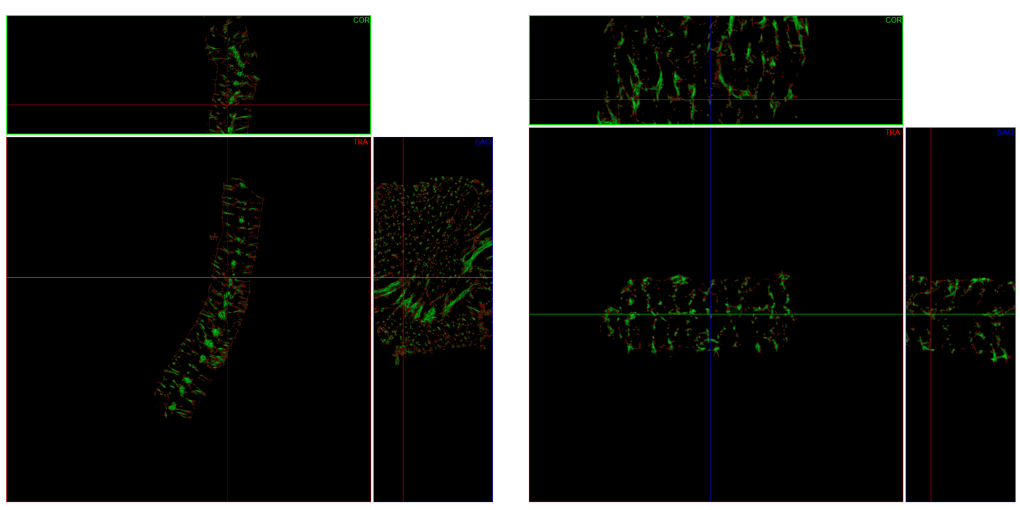

FIGURE 7 | Micro-CT representative coronal (COR), transverse (TRA) and sagittal (SAG) cross-sections of the skeletal of composition of the North Atlantic marine sponges. Each cross-section shows the sponge skeleton composition with the visualization of the organic matter (red) and inorganic matter (green).

each sponge was determined from the linear region of stressstrain curve.

As shown in Figure 10, the compressive modulus of Gb, $\mathrm{Ga}, \mathrm{Sn}, \mathrm{Pv}$, and $\mathrm{Ai}$ was $0.022 \pm 0.006$ vs. $0.021 \pm 0.016$ vs. $0.032 \pm 0.034$ vs. $0.142 \pm 0.081$ vs. $0.046 \pm 0.049$ $(\mathrm{MPa})$ respectively, assured mechanical values in the range of 0.021-0.142 $\mathrm{MPa}$ in the studied sponges. Among these sponge species, $\mathrm{Pv}$ showed the highest compressive strength, being statistically significant between $\mathrm{Gb}(p=0.036), \mathrm{Ga}$ $(p=0.0022)$ and $\operatorname{Sn}(p=0.0043)$ sponges (Figure 10). Regarding the uniaxial compression testing demonstrated an inverse relationship between the compressive modulus of $\mathrm{Pv}$, and the porosity and pore size. This means that a higher compressive modulus resulting in improvement of the mechanical properties showed the lowest porosity and pore size (Figures 8A,C). This phenomenon had been reported in other marine sponges as Spongia agaricina and Spongia lamella, whereas the reduction of porosity resulting in the enhancement of the mechanical properties (Boccardi et al., 2015b). Furthermore, these sponges provide scaffolds with higher mechanical properties (2-4-MPa). Recently study demonstrated that the skeletal architecture of marine glass sponge (Euplectella aspergillum) was used as biomodel for the 3D printing of structures with improved mechanical performance (Fernandes et al., 2020). The analyzed of mechanical behavior materials is relevant for biomimetic the properties of the skeletal tissues such as bone, cartilage, and tendon which present a very organized structure with structural functions (Zadpoor, 2015) also the evaluation of mechanical properties of biological tissue could be useful tool for diagnosis of diseases, as skins problem how collagen fibrils react to mechanical loading test (Nesbitt et al., 2015). However, to develop biomaterials with proper biological and mechanical properties that accurately fit these requirements, representing a gap in tissue engineering. For those reasons, scientist have investigating marine organisms to be used as models for biofabrication of new tissues engineering approaches. The compression strength of the sponges skeletons seems to require the mechanical properties of healthy soft $(0.5-70 \kappa \mathrm{Pa})$, and cancerous soft tissues $(20-560 \kappa \mathrm{Pa})$ (Hoskins, 2012).

\section{Sponges as Biomimetic Models for Tissue Engineering Application}

Marine sponges have a hierarchical architecture with spatial porous arrangement that may be an exceptional source of 


\section{Microstructure characterization}
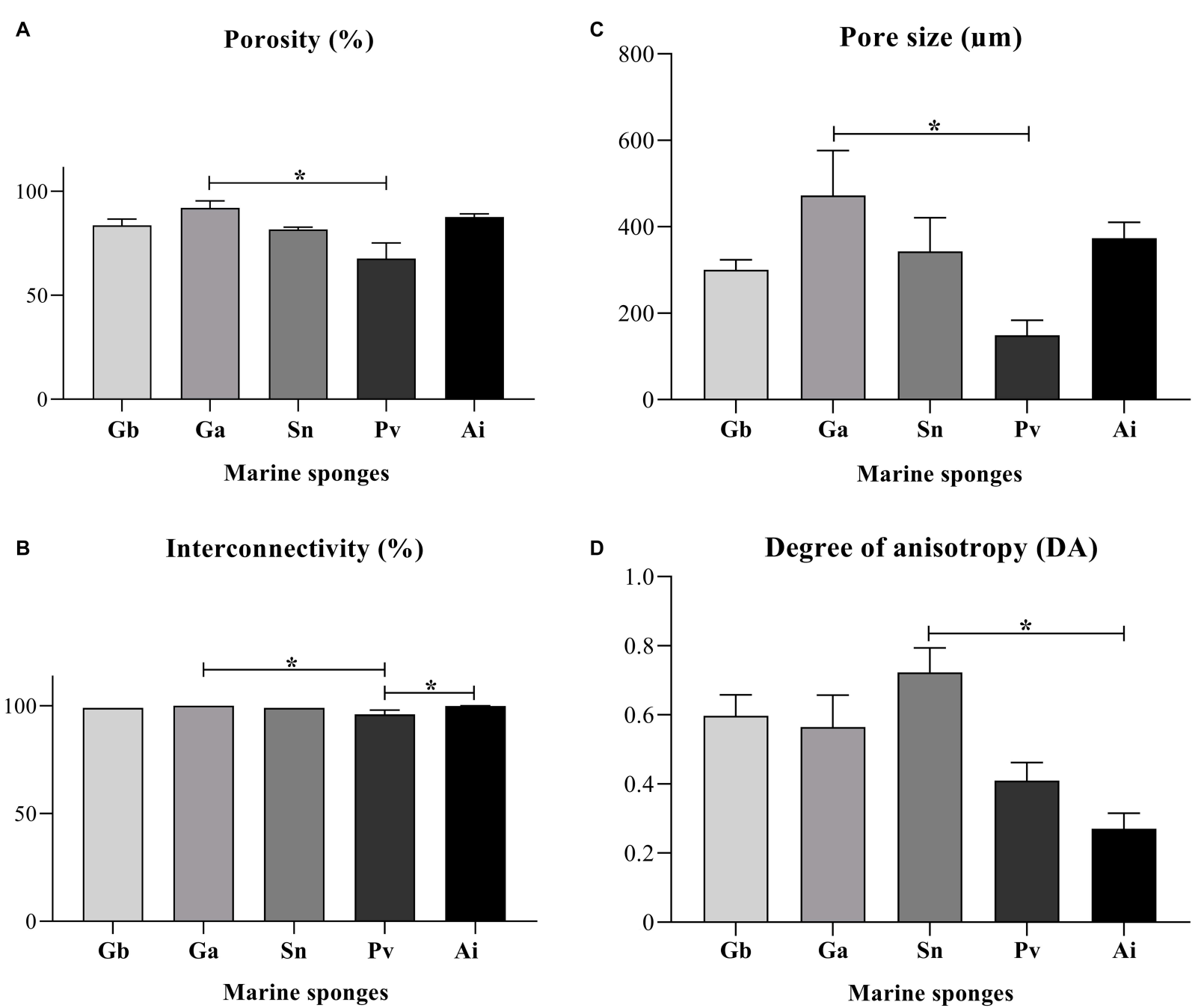

FIGURE 8 | Morphometric parameters of the 3D microstructure of the Geodia barretti (Gb), Geodia atlantica (Ga), Stelletta normani (Sn), Phakellia ventilabrum (Pv), and Axinella infundibuliformis (Ai). Micro-CT results for porosity (\%) (A), interconnectivity (\%) (B), pore size ( $\mu$ m) (C), and degree of anisotropy (DA) (D). Data expressed as mean \pm SD with three replicates per sponge species and the asterisks $\left({ }^{*}\right)$ indicate statistically significant differences $(p<0.05)$ after Kruskal-Wallis test with Dunn's multiple comparisons.

inspiration for being mimicked in tissue engineering (TE) approaches. These aquatic organisms can be used as models for the isolation of unique molecules or inspired frameworks for development of health applications including controlled drug delivery systems (Langasco et al., 2017), manufacturing of scaffolds (Ehrlich and Worch, 2007; Pallela et al., 2012) and hydrogels (Fassini et al., 2017; Ghosh et al., 2019).

The fabrication of biomaterials has widely been used with the main purpose of successful enhancement the biological properties improving clinical acceptance. These structures maintain adequately high cellular viability for being analogs of the extracellular matrix (ECM), promote the physical cell support and functions accomplished by structure of nature tissues (Mohanty et al., 2015) abundantly constituted by collagen biopolymer. The production of collagen-GAG scaffolds had shown that cell adhesion decreased with increasing mean pore size (O’Brien et al., 2005). However, related phenomena suggest occurring in marine sponges, whereas a lower pore size showed a considerable number of microorganisms. Behind that, the collagenous nature of marine sponge skeletons has been reported to promote attachment of human cells (Green et al., 2003; Murphy et al., 2010; Pozzolini et al., 2018).

The specific architecture of skeletons may influence the regeneration, pointed that sponges internal differentiation in a distinct cortex layer over the choanosome or into stalk and flared portion seems to have a lower regeneration (Wulff, 2010). Indeed, the spontaneous ability of sponge regeneration is affected 


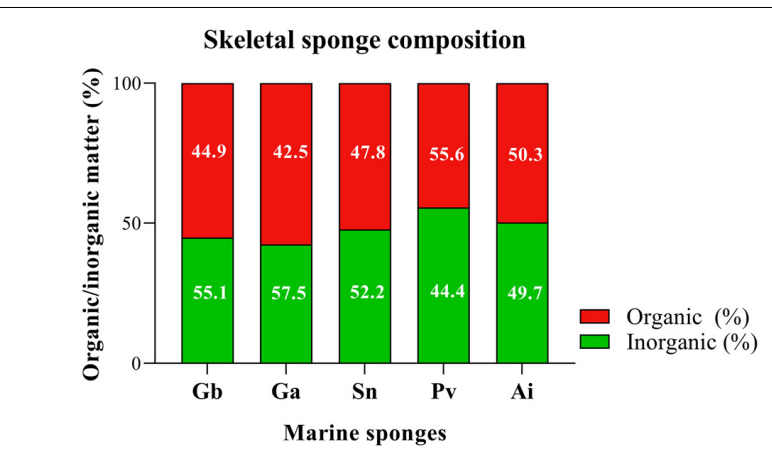

FIGURE 9 | Determination of structural composition of marine sponge of the Geodia barretti (Gb), Geodia atlantica (Ga), Stelletta normani (Sn), Phakellia ventilabrum (Pv), and Axinella infundibuliformis (Ai). Data expressed as mean of three replicates per sponge species and non-statistically significant differences $(p<0.05)$ after Kruskal-Wallis test with Dunn's multiple comparisons.

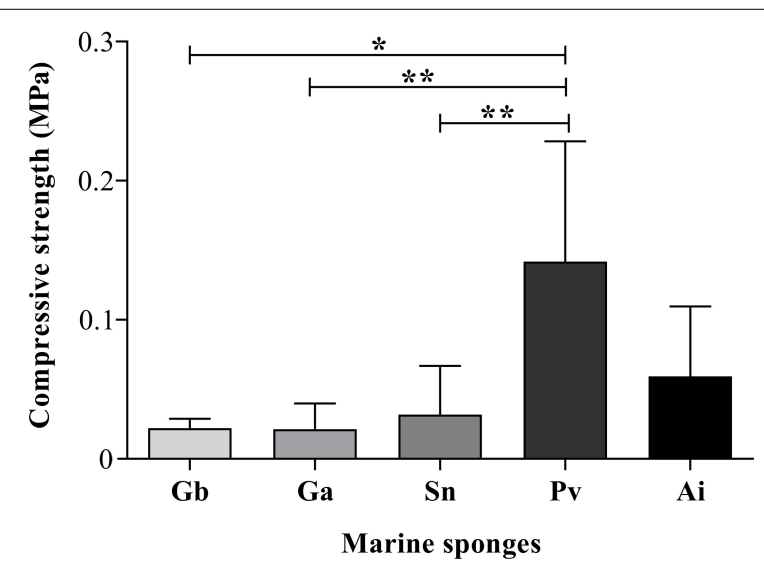

FIGURE 10 | Compressive modulus of the dried sponges. The asterisks indicate statistically significant differences $\left({ }^{*} p<0.05\right.$ or $\left.{ }^{* *} p<0.005\right)$ after Kruskal-Wallis test with Dunn's multiple comparisons.

by different factors, as the dimension of the wound or injured tissue (Osinga et al., 1999), similar to that occurs in human bone. Studies investigated the healing and regeneration process of G. barretti during 8 months, as the first effort for the production of sponge tissue (Hoffmann et al., 2003). Recently, it has been reported the regeneration of the body wall of Aplysina cavernicola demosponge after the formation of a blastemal mass composed of undifferentiated pluripotent cells involve for the regeneration and ensuring the wound healed within 2 weeks (Ereskovsky et al., 2019). As the sponge tissues, bone has the ability to regenerate and repair itself until at a certain defect size. Large bone defects, caused by degenerative diseases, trauma or tumor resection, are not predictable to regenerate, requiring new approaches to tackle this tissue loss, ideally by promoting its regeneration by inducing the formation of new bone with the purpose of restore the bone form and function (Gómez-Barrena et al., 2015; Fillingham and Jacobs, 2016).

In tissue engineering, mean pore size is a critical aspect for the fabrication of biomaterials. However, it is not consensual which is the optimal range of mean pore sizes required for an ideal tissue engineering approach, probably because it will differ with type of tissue, although a minimum pore size should be around $100 \mu \mathrm{m}$ to allow cell migration and proliferation to the interior of the scaffold (Karageorgiou and Kaplan, 2005). Nevertheless, it is consistently accepted that too large pores difficult the cell attachment due to the reduction of surface area available and too small pores limit the diffusion flows of gas, nutrients, growth factors as well as the elimination of the residual waste products (Murphy and O'Brien, 2010). Under the scope of different studies, scaffolds with larger pores (300-800 $\mu \mathrm{m})$ were reported to enhance the formation of new bone and capillaries, while scaffolds with smaller pores (96$150 \mu \mathrm{m})$ promote a better attachment of osteoblasts during the osteoconductivity mechanisms (Karageorgiou and Kaplan, 2005; Murphy and O’Brien, 2010). Also, Callyspongiidae demosponge in the literature was reported to have a skeleton with a pore dimension between 100 and $300 \mu \mathrm{m}$ wherein osteoblasts cells demonstrated the ability of anchor onto the surface of collagen fibers, being suitable biomaterial for bone tissue purpose (Lin et al., 2011). Furthermore, the anisotropic microstructure is also present on bone tissue that is constituted by an ordered arrangement of mostly collagen fibers, hydroxyapatite, and calcium phosphates materials (Szabó and Thurner, 2013; Tang et al., 2016; Ozasa et al., 2018). This is an important feature in biological systems, namely regarding cell-material interactions, with specific topographies seeming to positively influence the cell attachment and bioactivity on anisotropic scaffolds (Caliari and Harley, 2011). Also, the organization of cells in tissues are affected by the orientation of fibers in extracellular matrix that have a relevant role in the development and function of the tissue.

The composition of five demosponges studied after characterization of the morphology and chemical component, showed a presence of the organic and inorganic components with possible translation structure as a scaffold for bone tissue application. The skeletons of certain sponges and bone tissues are both composed by organic and inorganic compounds, constituting natural composites. In particular, bone is constituted by $30 \%$ of organic components namely collagen, polysaccharides, and other proteins, and $60 \%$ of the inorganic component as hydroxyapatite and calcium phosphates and $10 \%$ of the water (Feng, 2009). Independently of the composition of scaffolds, the future for regenerative purposes will encompass the manufacturing of nano to macroscopic levels of advanced unconventional biomaterials that mimic the chemical, biological and mechanical properties borrowed from nature in different therapeutic fields including bone, dermal, cardiac, muscle, neural and vascular (Khademhosseini and Langer, 2016; Nguyen and Camci-Unal, 2020).

\section{CONCLUSION}

Marine sponges own unique architectures with well spatial arrangement of skeleton components. Also, $\mu \mathrm{CT}$ and SEM analyses of five marine sponges confirmed the presence of highly 

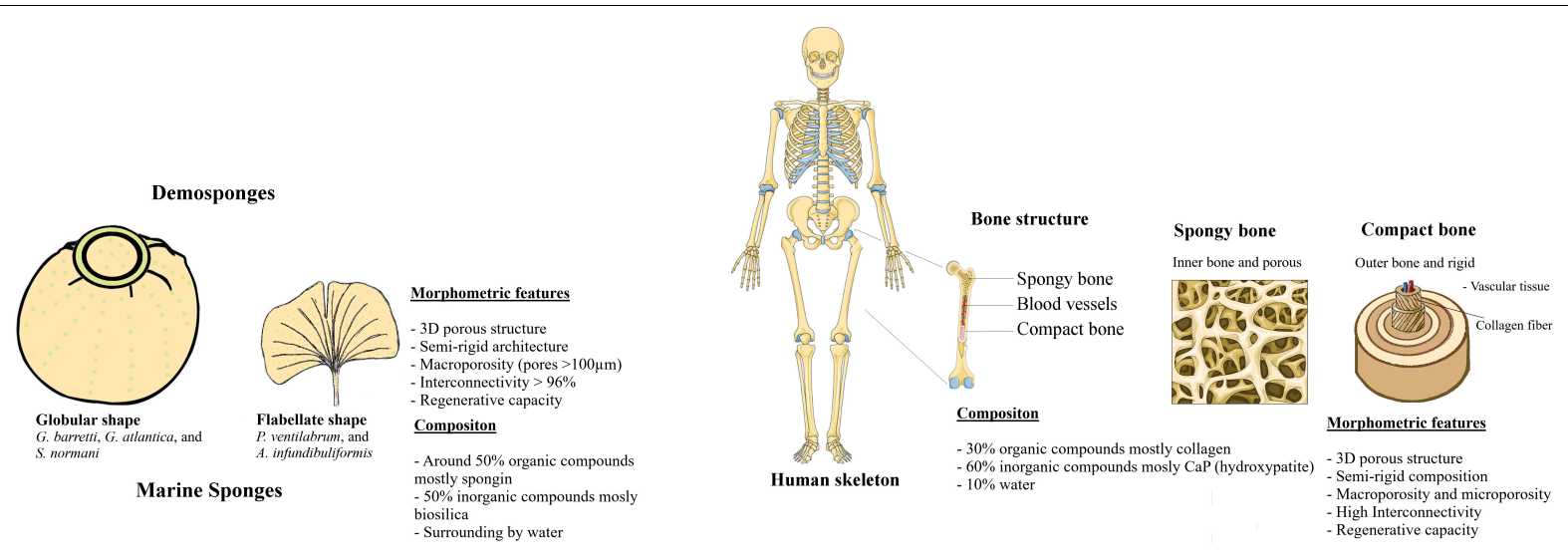

FIGURE 11 | Comparative morphological features of Marine Sponges and Human Bone tissue.

permeated 3D architecture constituted by a microscopic wellorganized interconnected channel. The studied demosponges were characterized by a porous $3 \mathrm{D}$ structure, in which pores exhibit a mean diameter ranging from 149 to $472 \mu \mathrm{m}$, highly interconnected and absorbent with a collagenous matrix skeleton. The skeletons of these marine sponges suggested having the pores in the range suitable for inducing bone ingrowth. The morphological topographical and physical features on the sponges have similarities with bone tissue (Figure 11), particularly its extracellular matrix. In this perspective, marine sponges can be strategic models for the development of biomaterials inspired on their porous and interconnected architecture.

Although all sponges shown a combination of organic and inorganic components in approximately equal volumes, their porosities and spatial organization was species dependent, with $\mathrm{Pv}$ displaying the denser structure and the members of the Axinellidae family, $\mathrm{PV}$ and $\mathrm{Ai}$, showing an isotropic structure. On the other hand, sponges are animals commonly acquainted by having high and rapid regeneration ratio, while regeneration mechanism of bone is a complex physiological process that occurs constantly along human life by means of remodeling and healing of bone mechanism not yet completely understood. Thus, the further study of marine sponges and the relation between the regenerative capacity and the morphological features may give new clues for the development of tissue engineering scaffolds with improved performance.

This study supports the use of marine sponges as noble candidates for the development of natural matrices, because skeletons of the marine sponges create a microenvironment favorable for the cell adhesion and proliferation. Also, sponge skeletons share structural analogies to the human extracellular matrices regarding the varied chemical composition and also some biologically features that having still few explored in the regeneration of tissues as a bone. Likewise, the architectural design of natural bone is a combination of various mechanical requirements as stiffness, strength, and toughness properties. These properties have been used for reinforcement and biomimetic the architecture of bone in the development of new materials (Gong et al., 2015).

\section{DATA AVAILABILITY STATEMENT}

The original contributions presented in the study are included in the article/Supplementary Material, further inquiries can be directed to the corresponding author/s.

\section{AUTHOR CONTRIBUTIONS}

EM designed and conceived the study, performed the experimental analyses, treated and discussed the results, and wrote the manuscript. HTR sampled the marine sponges' specimens, performed the sponge taxonomic identification, and responsible for funding. JRX contributed to study planning, sampled the marine sponges' specimens, performed the sponge taxonomic identification, discussed the results, and revised the manuscript. GSD supported the $\mu \mathrm{CT}$ analysis and revised the manuscript. RLR conceived the study, revised the manuscript, and responsible for funding. THS conceived and planned the study, discussed the results, and revised the manuscript. All the authors contributed to the work and approved the final version of the article.

\section{FUNDING}

The authors would like to acknowledge the funding from the European Union Framework Program for Research and Innovation Horizon 2020 through project SponGES (H2020BG-01-2015-679849) and from the Northern Portugal Regional Operational Program (NORTE2020), under the Portugal 2020 Partnership Agreement, through the Structured projects for R\&D\&I NORTE-01-0145-FEDER-000021 and NORTE-01-0145FEDER-000023. JRX research was further supported by national funds through FCT Foundation for Science and Technology within the scope of UIDB/04423/2020 and UIDP/04423/2020, and CEECIND/00577/2018. 


\section{SUPPLEMENTARY MATERIAL}

The Supplementary Material for this article can be found online at: https://www.frontiersin.org/articles/10.3389/fmars. 2020.613647/full\#supplementary-material

\section{REFERENCES}

Aguilar-Camacho, J. M., Doonan, L., and Mccormack, G. P. (2019). Evolution of the main skeleton-forming genes in sponges (Phylum porifera) with special focus on the marine Haplosclerida (class Demospongiae). Mol. Phylogenet. Evol. 131, 245-253. doi: 10.1016/j.ympev.2018.11.015

Aizenberg, J., Weaver, J. C., Thanawala, M. S., Sundar, V. C., Morse, D. E., and Fratzl, P. J. S. (2005). Skeleton of Euplectella $s p$ : structural hierarchy from the nanoscale to the macroscale. Science 309, 275-278. doi: 10.1126/science. 1112255

Alves, A. L., Marques, A. L., Martins, E., Silva, T. H., and Reis, R. L. (2017). Cosmetic potential of marine fish skin collagen. Cosmetics 4:39. doi: 10.3390/ cosmetics4040039

Azuma, K., Ifuku, S., Osaki, T., Okamoto, Y., and Minami, S. (2014). Preparation and biomedical applications of chitin and chitosan nanofibers. J. Biomed. Nanotechnol. 10, 2891-2920. doi: 10.1166/jbn.2014.1882

Belarbi, E. H., Gomez, A. C., Chisti, Y., Camacho, F. G. A., and Grima, E. M. (2003). Producing drugs from marine sponges. Biotechnol. Adv. 21, 585-598. doi: 10.1016/s0734-9750(03)00100-9

Bell, J. J. (2002). Regeneration rates of a sublittoral demosponge. J. Mar. Biol. Assoc. UK 82, 169-170. doi: 10.1017/s0025315402005295

Boccardi, E., Belova, I., Murch, G., Boccaccini, A., and Fiedler, T. (2015a). Oxygen diffusion in marine-derived tissue engineering scaffolds. J. Mater. Sci. Mater. Med. 26:200.

Boccardi, E., Philippart, A., Juhasz-Bortuzzo, J., Novajra, G., Vitale-Brovarone, C., and Boccaccini, A. R. (2015b). Characterisation of bioglass based foams developed via replication of natural marine sponges. Adv. Appl. Ceramics 114, S56-S62.

Borisenko, I. E., Adamska, M., Tokina, D. B., and Ereskovsky, A. V. (2015). Transdifferentiation is a driving force of regeneration in Halisarca dujardini (Demospongiae, Porifera). PeerJ 3:e1211. doi: 10.7717/peerj.1211

Burns, E., and Ilan, M. (2003). Comparison of anti-predatory defenses of red sea and caribbean sponges. II. physical defense. Mar. Ecol. Prog. Ser. 252, 115-123. doi: $10.3354 /$ meps 252115

Caliari, S. R., and Harley, B. A. (2011). The effect of anisotropic collagenGAG scaffolds and growth factor supplementation on tendon cell recruitment, alignment, and metabolic activity. Biomaterials 32, 5330-5340. doi: 10.1016/j. biomaterials.2011.04.021

Cárdenas, P., Rapp, H. T., Klitgaard, A. B., Best, M., Thollesson, M., and Tendal, O. S. (2013). Taxonomy, biogeography and DNA barcodes of Geodia species (Porifera, Demospongiae, Tetractinellida) in the Atlantic boreo-arctic region. Zool. J. Linn. Soc. 169, 251-311. doi: 10.1111/zoj.12056

Chattopadhyay, S., and Raines, R. T. (2014). Collagen-based biomaterials for wound healing. Biopolymers 101, 821-833. doi: 10.1002/bip.22486

Chiriboga, O. G., Leduff, P., and Rorrer, G. L. (2020). "Extracellular chitin nanofibers from marine diatoms," in Encyclopedia of Marine Biotechnology, ed. K. Se-Kwon (Hoboken, NJ: John Wiley).

Christy, P. N., Basha, S. K., Kumari, V. S., Bashir, A., Maaza, M., Kaviyarasu, K., et al. (2020). Biopolymeric nanocomposite scaffolds for bone tissue engineering applications-a review. J. Drug Deliv. Sci. Technol. 55:101452. doi: 10.1016/j. jddst.2019.101452

Clarke, J. (2003). The occurrence and significance of biogenic opal in the regolith. J. Earth-Sci. Rev. 60, 175-194. doi: 10.1016/s0012-8252(02)00092-2

Clarke, S., Choi, S., Mckechnie, M., Burke, G., Dunne, N., Walker, G., et al. (2016). Osteogenic cell response to 3-D Hydroxyapatite scaffolds developed via replication of natural marine sponges. J. Mater. Sci. Mater. Med. 27:22.

Coutinho, C. C., De Andrade Rosa, I., De Oliveira Teixeira, J. D., Andrade, L. R., Costa, M. L., and Mermelstein, C. (2017). Cellular migration, transition and interaction during regeneration of the sponge Hymeniacidon heliophila. PLoS One 12:e0178350. doi: 10.1371/journal.pone.0178350
Supplementary Material 1 | The determination of the ratios of the organic and inorganic elements present on the North Atlantic Sponges was accessed by micro-CT analyses and recorded in a video. 3D reconstruction of sponges was recorded in video to enable the visualization of the composition of the five demosponges namely, Geodia barretti, Geodia atlantica, Stelletta normani, Phakellia ventilabrum, and Axinella infundibuliformis.

Cunningham, E., Dunne, N., Walker, G., Maggs, C., Wilcox, R., and Buchanan, F. (2010). Hydroxyapatite bone substitutes developed via replication of natural marine sponges. J. Mater. Sci. Mater. Med. 21, 2255-2261. doi: 10.1007/s10856009-3961-4

De Vos, L., Rutzler, K., Boury-Esnault, N., Donadey, C., and Vacelet, J. (1991). Atlas of Sponge Morphology. Atlas de Morphologie Des Éponges. Washington, DC: Smithsonian Institution Press.

Diogo, G. S., Carneiro, F., Freitas-Ribeiro, S., Sotelo, C. G., Pérez-Martín, R. I., Pirraco, R. P., et al. (2020). Prionace glauca skin collagen bioengineered constructs as a promising approach to trigger cartilage regeneration. J. Mater. Sci. Eng. C (in press). doi: 10.1016/j.msec.2020.111587

Dong, C., and Lv, Y. (2016). Application of collagen scaffold in tissue engineering: recent advances and new perspectives. Polymers 8:42. doi: 10.3390/ polym8020042

Eckert, C., Schröder, H. C., Brandt, D., Perovic-Ottstadt, S., and Müller, W. E. (2006). Histochemical and electron microscopic analysis of spiculogenesis in the demosponge suberites domuncula. J. Histochem. Cytochem. 54, 1031-1040. doi: $10.1369 /$ jhc. 5 a6903.2006

Ehrlich, H. (ed.). (2019). "Enigmatic structural protein spongin," in Marine Biological Materials of Invertebrate Origin. Volume 13 of Biologically-Inspired Systems, (Berlin: Springer), 161-172. doi: 10.1007/978-3-319-92483-0_11

Ehrlich, H., Maldonado, M., Spindler, K. D., Eckert, C., Hanke, T., Born, R., et al. (2007). First evidence of chitin as a component of the skeletal fibers of marine sponges. part I. verongidae (Demospongia: Porifera). J. Exp. Zool. B Mol. Dev. Evol. 308, 347-356. doi: 10.1002/jez.b.21156

Ehrlich, H., Shaala, L. A., Youssef, D. T., Żółtowska-Aksamitowska, S., Tsurkan, M., Galli, R., et al. (2018a). Discovery of chitin in skeletons of non-verongiid red sea demosponges. PLoS One 13:e0195803. doi: 10.1371/journal.pone.0195803

Ehrlich, H., Simon, P., Carrillo-Cabrera, W., Bazhenov, V. V., Botting, J. P., Ilan, M., et al. (2010). Insights into chemistry of biological materials: newly discovered silica-aragonite-chitin biocomposites in demosponges. J. Chem. Mater. 22, 1462-1471. doi: 10.1021/cm9026607

Ehrlich, H., and Worch, H. (2007). "Sponges as natural composites: from biomimetic potential to development of new biomaterials," in Porifera Research: Biodiversity, Innovation \& Sustainability, eds Márcio Reis, G. Custódio, E. Lobo-Hajdu, G. Hajdu, and Muricy (Brazil: Museu Nacional), 217-223.

Ehrlich, H., Wysokowski, M., Żółtowska-Aksamitowska, S., Petrenko, I., and Jesionowski, T. (2018b). Collagens of poriferan origin. Mar. Drugs 16:79. doi: $10.3390 / \mathrm{md} 16030079$

Einhorn, T. A., and Gerstenfeld, L. C. (2015). Fracture healing: mechanisms and interventions. Nat. Rev. Rheumatol. 11, 45-54. doi: 10.1038/nrrheum.2014.164

Ereskovsky, A. V., Tokina, D. B., Saidov, D. M., Baghdiguian, S., Le Goff, E., and Lavrov, A. I. (2019). Transdifferentiation and mesenchymal-to-epithelial transition during regeneration in Demospongiae (Porifera). J. Exp. Zool. B Mol. Dev. Evol. 334, 37-58. doi: 10.1002/jez.b.22919

Exposito, J. Y., Cluzel, C., Garrone, R., and Lethias, C. (2002). Evolution of collagens. Anat. Rec. 268, 302-316. doi: 10.1002/ar.10162

Fassini, D., Duarte, A. R., Reis, R., and Silva, T. (2017). Bioinspiring chondrosia reniformis (Nardo, 1847) collagen-based hydrogel: a new extraction method to obtain a sticky and self-healing collagenous material. Mar. Drugs 15:380. doi: $10.3390 / \mathrm{md} 15120380$

Fassini, D., Oliveira, S. M., Silva, T. H., and Reis, R. L. (2020). "Biotechnological valorization of marine collagens: biomaterials for health applications," in Encyclopedia of Marine Biotechnology, ed. S.-K. Kim (Hoboken, NJ: John Wiley).

Feng, X. (2009). Chemical and biochemical basis of cell-bone matrix interaction in health and disease. Curr. Chem. Biol. 3, 189-196. doi: 10.2174/ 187231309788166398

Fernandes, M. C., Aizenberg, J., Weaver, J. C., and Bertoldi, K. (2020). Mechanically robust lattices inspired by deep-sea glass 
sponges. Nat. Mater. doi: 10.1038/s41563-020-0798-1 Online ahead of print.

Fillingham, Y., and Jacobs, J. (2016). Bone grafts and their substitutes. Bone Joint J. 98, 6-9.

Gabbai-Armelin, P., Kido, H., Cruz, M., Prado, J., Avanzi, I., Custódio, M., et al. (2019). Characterization and cytotoxicity evaluation of a marine sponge biosilica. Mar. Biotechnol. 21, 65-75. doi: 10.1007/s10126-018-9858-9

Gao, C., Peng, S., Feng, P., and Shuai, C. (2017). Bone biomaterials and interactions with stem cells. Bone Res. 5:17059.

Gazave, E., Lapébie, P., Ereskovsky, A. V., Vacelet, J., Renard, E., Cárdenas, P., et al. (2012). No longer Demospongiae: Homoscleromorpha formal nomination as a fourth class of Porifera. Hydrobiologia 687, 3-10. doi: 10.1007/s10750-0110842-x

Ghosh, A., Grosvenor, A. J., and Dyer, J. M. (2019). Marine spongia collagens: protein characterization and evaluation of hydrogel films. J. Appl. Polym. Sci. 136:47996. doi: 10.1002/app.47996

Gilis, M., Grauby, O., Willenz, P., Dubois, P., Heresanu, V., and Baronnet, A. (2013). Biomineralization in living Hypercalcified demosponges: toward a shared mechanism? J. Struct. Biol. 183, 441-454. doi: 10.1016/j.jsb.2013. 05.018

Gómez-Barrena, E., Rosset, P., Lozano, D., Stanovici, J., Ermthaller, C., and Gerbhard, F. (2015). Bone fracture healing: cell therapy in delayed unions and nonunions. Bone 70, 93-101. doi: 10.1016/j.bone.2014.07.033

Gong, T., Xie, J., Liao, J., Zhang, T., Lin, S., and Lin, Y. (2015). Nanomaterials and bone regeneration. Bone Res. 3:15029.

Granito, R. N., Custódio, M. R., and Rennó, A. C. M. (2017). Natural marine sponges for bone tissue engineering: the state of art and future perspectives. J. Biomed. Mater. Res. B Appl. Biomater. 105, 1717-1727. doi: 10.1002/jbm.b. 33706

Green, D., Howard, D., Yang, X., Kelly, M., and Oreffo, R. (2003). Natural marine sponge fiber skeleton: a biomimetic scaffold for human osteoprogenitor cell attachment, growth, and differentiation. Tissue Eng. 9, 1159-1166. doi: 10.1089/ 10763270360728062

Green, D. W., Padula, M., Santos, J., Chou, J., Milthorpe, B., and Ben-Nissan, B. (2013). A new role for marine skeletal proteins in regenerative orthopaedics. Key Eng. Mater. 529, 654-659. doi: 10.4028/www.scientific.net/kem.529-530. 654

Hoffmann, F., Rapp, H. T., Zöller, T., and Reitner, J. (2003). Growth and regeneration in cultivated fragments of the boreal deep water sponge Geodia barretti bowerbank, 1858 (Geodiidae, Tetractinellida, Demospongiae). J. Biotechnol. 100, 109-118. doi: 10.1016/s0168-1656(02)00258-4

Hooper, J. N., and Van Soest, R. W. (2002). “"Systema porifera"," in A guide to the classification of sponges systema porifera, eds N. A. John Hooper and R. W. M. van Soset (Boston, MA: Springer), 1-7. doi: 10.1007/978-1-4615-0747-5_1

Horton, T., Kroh, A., Ahyong, S., Bailly, N., Boury-Esnault, N., Brandão, S. N., et al. (2018). World Register of Marine Species. Available online at: https://www. marinespecies.org at VLIZ (accessed March 24, 2018)

Hoskins, P. R. (2012). Principles of ultrasound elastography. Ultrasound 20, 8-15. doi: 10.1258/ult.2011.011005

Jugdaohsingh, R. (2007). Silicon and bone health. J. Nutr. Health Aging 11, 99-110.

Karageorgiou, V., and Kaplan, D. (2005). Porosity of 3D biomaterial scaffolds and osteogenesis. Biomaterials 26, 5474-5491. doi: 10.1016/j.biomaterials.2005.02. 002

Kaya, M., Bilican, I., Mujtaba, M., Sargin, I., Haskoylu, M. E., Oner, E. T., et al. (2020). Sponge-derived natural bioactive glass microspheres with selfassembled surface channel arrays opening into a hollow core for bone tissue and controlled drug release applications. Chem. Eng. J. (in press). doi: 10.1016/ j.cej.2020.126667

Khademhosseini, A., and Langer, R. (2016). A decade of progress in tissue engineering. Nat. Protoc. 11, 1775-1781. doi: 10.1038/nprot.201 6.123

Kim, S. K., and Dewapriya, P. (2012). Bioactive compounds from marine sponges and their symbiotic microbes: a potential source of nutraceuticals. Adv. Food Nutr. Res. 65, 137-151. doi: 10.1016/b978-0-12-416003-3.00008-1

Klinger, C., Żółtowska-Aksamitowska, S., Wysokowski, M., Tsurkan, M. V., Galli, R., Petrenko, I., et al. (2019). Express method for isolation of ready-to-use 3D chitin scaffolds from Aplysina archeri (Aplysineidae: Verongiida) demosponge. Mar. Drugs 17:131. doi: 10.3390/md17020131
Klitgaard, A. B., and Tendal, O. S. (2004). Distribution and species composition of mass occurrences of large-sized sponges in the northeast Atlantic. Prog. Oceanogr. 61, 57-98. doi: 10.1016/j.pocean.20 04.06.002

Kovalchuk, V., Voronkina, A., Binnewerg, B., Schubert, M., Muzychka, L., Wysokowski, M., et al. (2019). Naturally drug-loaded chitin: isolation and applications. Mar. Drugs 17:574. doi: 10.3390/md17100574

Langasco, R., Cadeddu, B., Formato, M., Lepedda, A. J., Cossu, M., Giunchedi, P., et al. (2017). Natural collagenic skeleton of marine sponges in pharmaceutics: innovative biomaterial for topical drug delivery. Mater. Sci. Eng. 70, 710-720. doi: 10.1016/j.msec.2016.09.041

Lin, Z., Solomon, K. L., Zhang, X., Pavlos, N. J., Abel, T., Willers, C., et al. (2011). In vitro evaluation of natural marine sponge collagen as a scaffold for bone tissue engineering. Intl. J. of Biol. Sci. 7, 968-977. doi: 10.7150/ijbs. 7.968

Maldonado, M. (2009). Embryonic development of verongid demosponges supports the independent acquisition of spongin skeletons as an alternative to the siliceous skeleton of sponges. Biol. J. Linn. Soc. 97, 427-447. doi: 10.1111/j. 1095-8312.2009.01202.x

Martins, E., Rocha, M. S., Silva, T. H., and Reis, R. L. (2019). "Remarkable body architecture of marine sponges as biomimetic structure for application in tissue engineering," in Marine-Derived Biomaterials for Tissue Engineering Applications. Springer Series in Biomaterials Science and Engineering, eds A. H. Choi and B. Ben-Nissan (Berlin: Springer), 27-50. doi: 10.1007/978-981-138855-2_2

Mitchell, G. R., and Tojeira, A. (2013). Role of anisotropy in tissue engineering. Procedia Eng. 59, 117-125. doi: 10.1016/j.proeng.2013.05.100

Mohanty, S., Larsen, L. B., Trifol, J., Szabo, P., Burri, H. V. R., Canali, C., et al. (2015). Fabrication of scalable and structured tissue engineering scaffolds using water dissolvable sacrificial 3D printed moulds. Mater. Sci. Eng. 55, 569-578. doi: 10.1016/j.msec.2015.06.002

Müller, W. E., Boreiko, A., Wang, X., Krasko, A., Geurtsen, W., Custódio, M. R., et al. (2007). Morphogenetic activity of silica and bio-silica on the expression of genes controlling biomineralization using SaOS-2 cells. Calcif. Tissue Int. 81, 382-393. doi: 10.1007/s00223-007-9075-4

Murillo, F. J., Muñoz, P. D., Cristobo, J., Ríos, P., González, C., Kenchington, E., et al. (2012). Deep-sea sponge grounds of the flemish cap, flemish pass and the grand banks of newfoundland (Northwest Atlantic Ocean): distribution and species composition. Mar. Biol. Res. 8, 842-854. doi: 10.1080/17451000.2012. 682583

Murphy, C. M., Haugh, M. G., and O'brien, F. J. (2010). The effect of mean pore size on cell attachment, proliferation and migration in collagen-glycosaminoglycan scaffolds for bone tissue engineering. Biomaterials 31, 461-466. doi: 10.1016/j. biomaterials.2009.09.063

Murphy, C. M., and O’Brien, F. J. (2010). Understanding the effect of mean pore size on cell activity in collagen-glycosaminoglycan scaffolds. Cell Adh. Migr. 4, 377-381. doi: 10.4161/cam.4.3.11747

Mutsenko, V. V., Bazhenov, V. V., Rogulska, O., Tarusin, D. N., Schütz, K., Brüggemeier, S., et al. (2017a). 3D chitinous scaffolds derived from cultivated marine demosponge Aplysina aerophoba for tissue engineering approaches based on human mesenchymal stromal cells. Int. J. Biol. Macromol. 104, 1966-1974. doi: 10.1016/j.ijbiomac.2017.03.116

Mutsenko, V. V., Gryshkov, O., Lauterboeck, L., Rogulska, O., Tarusin, D. N., Bazhenov, V. V., et al. (2017b). Novel chitin scaffolds derived from marine sponge Ianthella basta for tissue engineering approaches based on human mesenchymal stromal cells: biocompatibility and cryopreservation. Int. J. Biol. Macromol. 104, 1955-1965. doi: 10.1016/j.ijbiomac.2017.03.161

Nakayama, S., Arima, K., Kawai, K., Mohri, K., Inui, C., Sugano, W., et al. (2015). Dynamic transport and cementation of skeletal elements build up the pole-andbeam structured skeleton of sponges. Curr. Biol. 25, 2549-2554. doi: 10.1016/j. cub.2015.08.023

Nandi, S. K., Kundu, B., Mahato, A., Thakur, N. L., Joardar, S. N., and Mandal, B. B. (2015). In vitro and in vivo evaluation of the marine sponge skeleton as a bone mimicking biomaterial. Integr. Biol. 7, 250-262. doi: 10.1039/c4ib00289j

Nesbitt, S., Scott, W., Macione, J., and Kotha, S. (2015). Collagen fibrils in skin orient in the direction of applied uniaxial load in proportion to stress while exhibiting differential strains around hair follicles. Materials 8, 1841-1857. doi: $10.3390 / \mathrm{ma} 8041841$ 
Nguyen, M. A., and Camci-Unal, G. (2020). Unconventional tissue engineering materials in disguise. Trends Biotechnol. 38, 178-190. doi: 10.1016/j.tibtech. 2019.07.014

Nickel, M., and Brümmer, F. (2003). In vitro sponge fragment culture of Chondrosia reniformis (Nardo, 1847). J. Biotechnol. 100, 147-159. doi: 10.1016/ s0168-1656(02)00256-0

O'Brien, F. J., Harley, B., Yannas, I. V., and Gibson, L. J. (2005). The effect of pore size on cell adhesion in collagen-GAG scaffolds. Biomaterials 26, 433-441. doi: 10.1016/j.biomaterials.2004.02.052

Osinga, R., Tramper, J., and Wijffels, R. H. (1999). Cultivation of marine sponges. Mar. Biotechnol. 1, 509-532. doi: 10.1007/pl00011807

Ozasa, R., Matsugaki, A., Isobe, Y., Saku, T., Yun, H. S., and Nakano, T. (2018). Construction of human induced pluripotent stem cell-derived oriented bone matrix microstructure by using in vitro engineered anisotropic culture model. J. Biomed. Mater. Res. A 106, 360-369. doi: 10.1002/jbm.a.36238

Pallela, R., Venkatesan, J., Janapala, V. R., and Kim, S. K. (2012). Biophysicochemical evaluation of chitosan-hydroxyapatite-marine sponge collagen composite for bone tissue engineering. J. Biomed. Mater. Res. A 100, 486-495. doi: 10.1002/jbm.a.33292

Philibert, T., Lee, B. H., and Fabien, N. J. A. B. (2017). Current status and new perspectives on chitin and chitosan as functional biopolymers. Appl. Biochem. Biotechnol. 181, 1314-1337. doi: 10.1007/s12010-0162286-2

Pozzolini, M., Gallus, L., Ghignone, S., Ferrando, S., Candiani, S., Bozzo, M., et al. (2019). Insights into the evolution of metazoan regenerative mechanisms: roles of TGF superfamily members in tissue regeneration of the marine sponge chondrosia reniformis. J. Exp. Biol. 222:jeb207894. doi: 10.1242/jeb. 207894

Pozzolini, M., Scarfi, S., Gallus, L., Castellano, M., Vicini, S., Cortese, K., et al. (2018). Production, characterization and biocompatibility evaluation of collagen membranes derived from marine sponge chondrosia reniformis nardo, 1847. Mar. Drugs 16:111. doi: 10.3390/md16040111

Ramshaw, J. A., Peng, Y. Y., Glattauer, V., and Werkmeister, J. A. (2009). Collagens as biomaterials. J. Mater. Sci. Mater. Med. 20, S3-S8.

Sandford, F. (2003). Physical and chemical analysis of the siliceous skeletons in six sponges of two groups (Demospongiae and Hexactinellida). Microsc. Res. Tech. 62, 336-355. doi: 10.1002/jemt.10400

Santos, V. P., Marques, N. S. S., Maia, P. C. S. V., Lima, M. A. B., Franco, L. O., and Campos-Takaki, G. M. (2020). Seafood waste as attractive source of chitin and chitosan production and their applications. Intl. J. Mol. Sci. 21:4290. doi: 10.3390/ijms21124290

Schröder, H. C., Boreiko, O., Krasko, A., Reiber, A., Schwertner, H., and Müller, W. E. (2005). Mineralization of SaOS-2 cells on enzymatically (silicatein) modified bioactive osteoblast-stimulating surfaces. J. Biomed. Mater. Res. B Appl. Biomater. 75, 387-392. doi: 10.1002/jbm.b.30322

Schubert, M., Binnewerg, B., Voronkina, A., Muzychka, L., Wysokowski, M., Petrenko, I., et al. (2019). Naturally prefabricated marine biomaterials: isolation and applications of flat chitinous 3D scaffolds from ianthella labyrinthus (Demospongiae: Verongiida). Intl. J. Mol. Sci. 20:5105. doi: 10.3390/ ijms 20205105

Seixas, M. J., Martins, E., Reis, R. L., and Silva, T. H. (2020). Extraction and characterization of collagen from elasmobranch byproducts for potential biomaterial use. Mar. Drugs 18:E617. doi: 10.3390/md18120617

Shaala, L. A., Asfour, H. Z., Youssef, D. T., Żółtowska-Aksamitowska, S., Wysokowski, M., Tsurkan, M., et al. (2019). New source of 3D chitin scaffolds: the red sea demosponge Pseudoceratina arabica (Pseudoceratinidae, Verongiida). Mar. Drugs 17:92. doi: 10.3390/md17020092

Silva, J. O. C., Barros, A. A., Aroso, I. M., Fassini, D., Silva, T. H., Reis, R. L., et al. (2016). Extraction of collagen/gelatin from the marine demosponge chondrosia reniformis (Nardo, 1847) using water acidified with carbon dioxide-process optimization. Ind. Eng. Chem. Res. 55, 6922-6930. doi: 10.1021/acs.iecr. 6b00523

Silva, T. H., Alves, A., Ferreira, B., Oliveira, J. M., Reys, L., Ferreira, R., et al. (2012). Materials of marine origin: a review on polymers and ceramics of biomedical interest. Intl. Mater. Rev. 57, 276-306. doi: 10.1179/1743280412y.0000000002

Silva, T. H., Moreira-Silva, J., Marques, A. L., Domingues, A., Bayon, Y., and Reis, R. L. (2014). Marine origin collagens and its potential applications. Mar. Drugs 12, 5881-5901. doi: $10.3390 / \mathrm{md} 12125881$
Silvipriya, K., Kumar, K. K., Bhat, A., Kumar, B. D., John, A., and Lakshmanan, P. (2015). Collagen: animal sources and biomedical application. J. Appl. Pharm. Sci. 5, 123-127. doi: 10.7324/japs.2015.50322

Simion, P., Philippe, H., Baurain, D., Jager, M., Richter, D. J., Di Franco, A., et al. (2017). A large and consistent phylogenomic dataset supports sponges as the sister group to all other animals. Curr. Biol. 27, 958-967. doi: 10.1016/j.cub. 2017.02.031

Singh, D., and Shrivastava, A. K. (2020). "Chitin: promising biopolymer for biomedical application," in New and Future Developments in Microbial Biotechnology and Bioengineering, ed. V. K. Gupta (Amsterdam: Elsevier Science), 175-185. doi: 10.1016/b978-0-12-821006-2.00013-3

Singh, D. K., and Ray, A. R. (2000). Biomedical applications of chitin, chitosan, and their derivatives. J. Macromol. Sci. C. Polym. Rev. 40, 69-83.

Smith, A. M., Berman, J., Key, M. M. Jr., and Winter, D. J. (2013). Not all sponges will thrive in a high-CO2 ocean: review of the mineralogy of calcifying sponges. Palaeogeogr. Palaeoclimatol. Palaeoecol. 392, 463-472. doi: 10.1016/j.palaeo. 2013.10.004

Sorushanova, A., Delgado, L. M., Wu, Z., Shologu, N., Kshirsagar, A., Raghunath, R., et al. (2019). The collagen suprafamily: from biosynthesis to advanced biomaterial development. Adv. Mater. 31:e1801651.

Sousa, R. O., Alves, A. L., Carvalho, D. N., Martins, E., Oliveira, C., Silva, T. H., et al. (2020a). Acid and enzymatic extraction of collagen from Atlantic cod (Gadus Morhua) swim bladders envisaging health-related applications. J. Biomater. Sci. Polym. Ed. 31, 20-37. doi: 10.1080/09205063.2019.1669313

Sousa, R. O., Martins, E., Carvalho, D. N., Alves, A. L., Oliveira, C., Duarte, A. R. C., et al. (2020b). Collagen from Atlantic cod (Gadus morhua) skins extracted using CO 2 acidified water with potential application in healthcare. J. Polym. Res. 27:73.

Suga, H., Ono, K., and Miyata, T. (1999). Multiple TGF- $\beta$ receptor related genes in sponge and ancient gene duplications before the parazoan-eumetazoan split. FEBS Lett. 453, 346-350. doi: 10.1016/s0014-5793(99)00749-8

Szabó, M., and Thurner, P. J. (2013). Anisotropy of bovine cortical bone tissue damage properties. J. Biomech. 46, 2-6. doi: 10.1016/j.jbiomech.2012. 08.002

Tang, D., Tare, R. S., Yang, L.-Y., Williams, D. F., Ou, K.-L., and Oreffo, R. O. (2016). Biofabrication of bone tissue: approaches, challenges and translation for bone regeneration. Biomaterials 83, 363-382. doi: 10.1016/j.biomaterials.2016. 01.024

Taylor, M. W., Radax, R., Steger, D., and Wagner, M. (2007). Sponge-associated microorganisms: evolution, ecology, and biotechnological potential. Microbiol. Mol. Biol. Rev. 71, 295-347. doi: 10.1128/mmbr.00040-06

Uriz, M. J. (2002). “Family geodiidae gray, 1867,” in Systema Porifera, eds R. W. M. van Soest and N. A. John Hooper (Boston, MA: Springer), 134-140. doi: 10. 1007/978-1-4615-0747-5_14

Uriz, M. J. (2006). Mineral skeletogenesis in sponges. Can. J. Zool. 84, 322-356. doi: 10.1139/z06-032

Wang, G. (2006). Diversity and biotechnological potential of the sponge-associated microbial consortia. J. Ind. Microbiol. Biotechnol. 33, 545-551. doi: 10.1007/ s10295-006-0123-2

Webster, N. S., and Taylor, M. W. (2012). Marine sponges and their microbial symbionts: love and other relationships. Environ. Microbiol. 14, 335-346. doi: 10.1111/j.1462-2920.2011.02460.x

Weisz, J. B., Lindquist, N., and Martens, C. S. (2008). Do associated microbial abundances impact marine demosponge pumping rates and tissue densities? Oecologia 155, 367-376. doi: 10.1007/s00442-007-0910-0

Wörheide, G., Dohrmann, M., Erpenbeck, D., Larroux, C., Maldonado, M., Voigt, O., et al. (2012). "Deep phylogeny and evolution of sponges (phylum porifera)," in Advances in Marine Biology, eds M. A. Becerro, M. J. Uriz, M. Maldonado, and X. Turon (Cambridge, MA: Academic Press), 1-78. doi: 10.1016/b978-012-387787-1.00007-6

Wulff, J. (2010). Regeneration of sponges in ecological context: is regeneration an integral part of life history and morphological strategies? Integr. Comp. Biol. 50, 494-505. doi: 10.1093/icb/icq100

Wysokowski, M., Jesionowski, T., and Ehrlich, H. (2018). Biosilica as a source for inspiration in biological materials science. Am. Mineral. J. Earth Planetary Mater. 103, 665-691. doi: 10.2138/am-2018-6429

Yahel, G., Sharp, J. H., Marie, D., Häse, C., and Genin, A. (2003). In situ feeding and element removal in the symbiont-bearing sponge Theonella swinhoei: bulk 
DOC is the major source for carbon. Limnol. Oceanogr. 48, 141-149. doi: 10.4319/lo.2003.48.1.0141

Yannas, I. (1992). Tissue regeneration by use of collagen-glycosaminoglycan copolymers. Clin. Mater. 9, 179-187. doi: 10.1016/0267-6605(92)90 098-e

Younes, I., Hajji, S., Frachet, V., Rinaudo, M., Jellouli, K., and Nasri, M. (2014). Chitin extraction from shrimp shell using enzymatic treatment. antitumor, antioxidant and antimicrobial activities of chitosan. Intl. J. Biol. Macromol. 69, 489-498. doi: 10.1016/j.ijbiomac.2014.06.013

Zadpoor, A. A. (2015). Mechanics of biological tissues and biomaterials. current trends. Materials 21, 4505-4511. doi: 10.3390/ma8074505

Żółtowska-Aksamitowska, S., Shaala, L. A., Youssef, D. T., Elhady, S. S., Tsurkan, M. V., Petrenko, I., et al. (2018). First report on chitin in a non-verongiid marine demosponge: the mycale euplectellioides case. Mar. Drugs 16:68. doi: $10.3390 / \mathrm{md} 16020068$

Conflict of Interest: The authors declare that the research was conducted in the absence of any commercial or financial relationships that could be construed as a potential conflict of interest.

Copyright $\odot 2021$ Martins, Rapp, Xavier, Diogo, Reis and Silva. This is an open-access article distributed under the terms of the Creative Commons Attribution License (CC BY). The use, distribution or reproduction in other forums is permitted, provided the original author(s) and the copyright owner(s) are credited and that the original publication in this journal is cited, in accordance with accepted academic practice. No use, distribution or reproduction is permitted which does not comply with these terms. 